Portland State University

PDXScholar

1990

\title{
The enigmatic founder : liberalism, republicanism and the thought of James Madison
}

John S. Witherow

Portland State University

Follow this and additional works at: https://pdxscholar.library.pdx.edu/open_access_etds

Part of the Political History Commons

Let us know how access to this document benefits you.

Recommended Citation

Witherow, John S., "The enigmatic founder : liberalism, republicanism and the thought of James Madison" (1990). Dissertations and Theses. Paper 4113.

https://doi.org/10.15760/etd.5997

This Thesis is brought to you for free and open access. It has been accepted for inclusion in Dissertations and Theses by an authorized administrator of PDXScholar. Please contact us if we can make this document more accessible: pdxscholar@pdx.edu. 
AN ABSTRACT OF THE THESIS OF John S. Witherow for the Master of Arts in History presented July 12, 1990.

Title: The Enigmatic Founder: Liberalism, Republicanism, and the Thought of James Madison.

APPROVED BY THE MEMBERS OF FHE THESIS COMMITTEE:

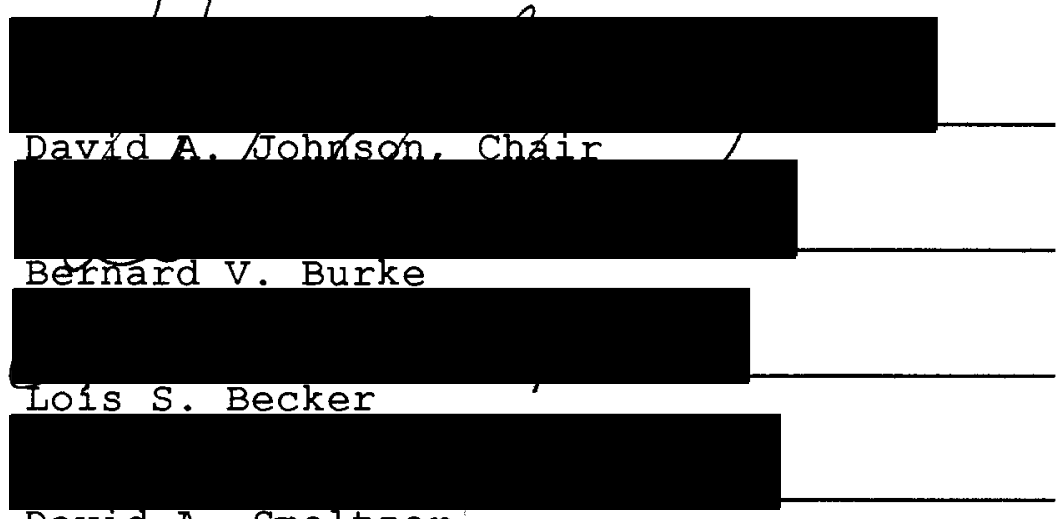

David A. Smeltzer

In the twentieth century the debate over the ideological origins of the founding period and early republic has resulted in a polarization of historical interpretations. Recently, the conflict has centered on historians who use either the liberal or classical republican paradigms to explain these eras. Scholars of the founding period have argued for the dominance of one political ideology or the other in the thought of important figures of this time. Unfortunately, this struggle has led to a narrow interpretation of arguably the greatest thinker in American History, James Madison. To the contrary, I hold Madison's thought was influenced by both liberal and 
classical republican ideas, and in this thesis I explore that interpretation.

The bulk of the primary sources upon which this thesis rests come from the most current edition of Madison's writings, a fifteen volume set that runs through 1795 . Contrary to conventional methods of analyzing Madison's thought that stress his famous public works, in particular The Federalist, this thesis gives Madison's private correspondence equal attention on the grounds that in them Madison elaborated his ideas most fully. Using such an approach led to an interpretation of Madison as both a liberal and republican thinker. In this regard I present his thought as sui generis and influenced by more than one ideology.

The organization of the thesis is governed by my presentation of Madison as sui generis. In chapter two, where I discuss Madison's thought on the nation's security, the republican Madison comes to the forefront. On this point, he combined English opposition convictions about the need for a vigilant citizenry with complementary republican ideas drawn from Montesquieu concerned with providing wisdom and stability in government. Madison used portions of both to forge ideological weapons designed to protect the republic.

However, Madison also heartily embraced liberal doctrines, my topic in chapter three. With regard to the 
concept of natural rights, there was never a more committed advocate of inalienable rights than he. In addition, his theory of interest was a more positive doctrine than current historians, who have studied Madison's theory of interest solely through The Eederalist, recognize. Madison understood that advancement of the public good occurred only when lawmakers understood the varied interests of the nation. Despite historians' rhetoric to the contrary, in Madison's mind liberalism and republicanism were not antithetical.

Nowhere is Madison's joining of liberal and republican ideas clearer than in his views on political economy. This part of his ideology, the best example of the way he wove together portions of both ideologies, is the focus of chapter four. Madison glorified the virtuous farmer as the bulwark of the republic. However, he also encouraged development of a robust, aggressive, commerce based on agricultural surplus. To his mind, agriculture maintained republican character, and exporting of surpluses provided individuals the opportunity to pursue their innate desire for self betterment.

Interpretations of Madison's thought suffer, in short, because historians focus on single ideological paradigms and, in doing so, use sources narrowly. One ideology, either liberal or republican, and one source, specifically The Federalist, cannot adequately explain this thinker. 
THE ENIGMATIC FOUNDER: LIBERALISM, REPUBLICANISM AND THE THOUGHT OF JAMES MADISON

by

JOHN S. WITHEROW

A thesis submitted in partial fulfillment of the requirements for the degree of

\author{
MASTER OF ARTS \\ in \\ HISTORY
}

Portland State University

1990 
TO THE OFFICE OF GRADUATE STUDIES:

The members of the Committee approve the thesis of John S. Witherow presented July 12, 1990.

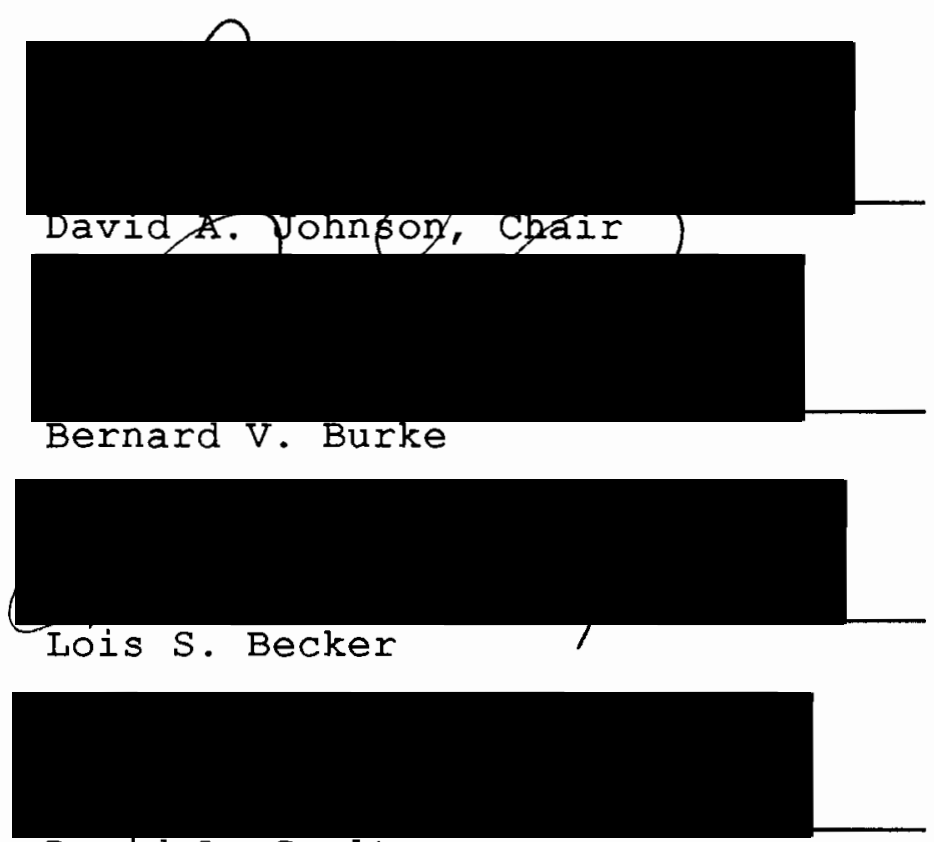

David A. Smeltzer

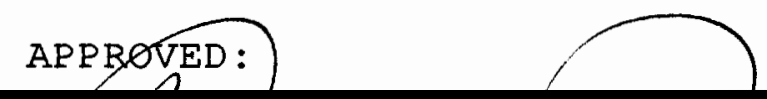

Bernard V. Burke, Chair, Department of History

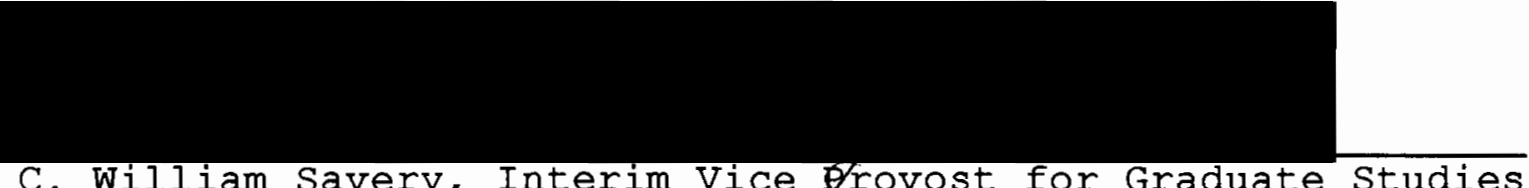
and Research 
TABLE OF CONTENTS

PAGE

CHAPTER

I INTRODUCTION. . . . . . . . . . . . . . . . . 1

I THE CLASSICAL MADISON: TYRANNY AND VIRTUE. . . 21

III THE LIBERAL MADISON: NATURAL RIGHTS AND INTEREST. . . . . . . . . . . . . 60

IV THE SUI GENERIS MADISON: A PRUDENT POLITICAL ECONOMY. . . . . . . . . . . . . . . 101

V CONCLUSION. . . . . . . . . . . . . 137

WORKS CONSULTED. . . . . . . . . . . . . . . . 141 
CHAPTER I

INTRODUCTION

According to historian Peter Onuf many scholars view the recent Constitutional bicentennial as an intellectual failure because it failed to produce new interpretations of the founding period. However, onuf took issue with this conclusion on the grounds that critics did not understand how interpretations regarding this epoch were "being redefined." ${ }^{1}$ To onuf the recent debate over the intellectual heritage of the founding period had contributed to a greater understanding of the "complexities of American republican thought." 2 With regard to James Madison, one of the most enigmatic yet essential actors of this period, Onuf's observation deserves serious attention.

Despite the longevity of his career and his prominent role in politics from the Revolution until his death in 1836, Madison has not captured anywhere near the scholarly attention as have Washington, Adams, Jefferson, and Hamilton. Arguably, he contributed more in the long run to the American republic than any of the others. He served as

1 Peter S. Onuf, "Reflections on the Founding: Constitutional Historiography in Bicentennial Perspective," William and Mary Quarterly, 46.2 (April 1989), 341-375, 341.

2 Ibid., 342. 
a political theoretician, a representative at both the national and local level, secretary of State, and President. In retirement he remained active as a political "guru" of the republic.

The very complexity of Madison's thought and the longevity of his career makes him difficult to pin down. Even today noted scholars back away from tackling his career and thought in full. ${ }^{3}$ While acknowledging the richness and diversity of Madison's thought, little in the way of serious effort has been given to drawing out the complexity of his mind. Scholars have described Madison as acting from a singular motive or ideology. Two ideological interpretations, in particular, have dominated Madison studies.

Currently, the debate over Madison's ideology centers on his ideas as exclusively "republican" or "liberal." Scholars applying one paradigm or the other have depicted Madison as either a selfless patriot or scheming aristocrat. Historians such as J.G.A. Pocock, Caroline Robbins, Bernard Bailyn, Gordon Wood, Lance Banning, and Drew McCoy, who use the republican paradigm, have traced the development and transformation of its ideology from ancient Greece, to

3 Two conspicuous examples are Robert Rutland, James Madison: The Founding Father (New York: McMillian, 1987), which focuses on Madison's life after the Constitutional Convention of 1787, and Drew McCoy's recent, The Last of the Founding Fathers (Cambridge: Cambridge University Press, 1989), which deals above all with Madison's views on slavery, primarily after 1815 . 
sixteenth century florentine, Italy, seventeenth century England, and finally to eighteenth century America. ${ }^{4}$ According to scholars who apply the republican paradigm, the Founding Fathers drew deeply on republican doctrine during the Revolution and the republic's formative years. Central to these scholars' delineation of republican doctrine is the concept of virtue. Virtue in a republican context referred to the public good, that is the ability of a republic's citizenry to put public needs above private desires. Virtue in this manner demanded a certain political and social order designed to insure a republic's survival. A political system which balanced power between an executive, legislative, and judicial branch was essential. Basically a static theory, classical republicanism defined the state as an organic entity. Republican doctrine held that change in the political structure was evil. Every alteration indicated an increase in age and pointed to a corruption of the society's fundamental principles, a sure sign of a republic's decay and inevitable destruction.

According to the theory, a republic must remain small to guarantee that its citizens remained a homogenous body dedicated to public matters. Republican theory insisted, furthermore, on the necessity of its members economic independence. Equality among citizens was an important component of the social order. While equality did not refer

${ }^{4}$ For a list of relevant works see below, note twelve. 
to an absolute, equal distribution of wealth, it did allude to a type of economic parity in which citizens avoided dependence on others for their livelihood. Usually an agrarian lifestyle gained prominence over others because in theory it allowed citizens to provide for themselves without relying on others. This independence allowed the body politic to remain pure, and thwart those who might use economic coercion to advance their self interest at the expense of the public. By the same token, self interest was viewed as evil. It corrupted the republic's collective character, and threatened its stability by introducing values that destroyed the public, homogenous nature which held the community together. Republican ideology denied the individual, and instructed citizens to devote themselves to public service.

In contrast to historians who stress classical republican tenets as the basis for the founding era, those historians who emphasize the discourse of liberalism--Louis Hartz, Joyce Appleby, John Patrick Diggins, and Issac Kramnick, in particular--maintain an ideology of individualism comprised the principles upon which American politics was based. 5 Drawn from the works of John Locke and Adam Smith, liberalism held that the best society is one that allows the individual to advance his self interest.

5 Important liberal sources are cited in notes fourteen, fifteen and sixteen. 
Government's role was small, and consisted mainly of governing only enough to insure that all had a fair opportunity to develop their economic potential.

Liberalism, then, encouraged individual self interest. Equality of opportunity was the watchword of its adherents. Whereas republican doctrine demanded that citizens share the quality of civic virtue, liberal doctrine emphasized the right--the so-called natural right--of individuals to choose their own religious, economic and political values. From the liberal perspective progress took on a more positive light. Rather than an indication of decay, it signified a positive step. Change was a natural characteristic of an aggressive, individualistic people putting their abilities to work. Historians of the liberal persuasion see the values of self interest, competition, and economic development beyond the countryside providing a national ideological consensus.

The idea of self interest, then, undergirds the liberal interpretation of the founding epoch, just as the concept of virtue bolsters the republican. Understood in such a manner, these definitions provide the pivot upon which this thesis turns. Those who have written about Madison have tended to make him into either a republican or liberal. Madison scholarship seems like a tug of war, with Madison caught in the middle. Each side has attempted to pull his character to one side and explain his actions through a one 
dimensional interpretative framework.

While this thesis surveys Madison's political theory in light of considerations raised by recent scholarship on the republican and liberal tradition, it is important to note that published studies of this founder throughout the twentieth century have been marked by narrow, one dimensional portraits. Progressive historians, reacting in the early twentieth century against what they considered as uncritical, reverential nineteenth century interpretations of the founding period, followed the lead of J. Allen Smith. Smith's The Spirit of American Government was the opening salvo in the Progressive attack on the men at the Constitutional Convention, one of whom was James Madison. ${ }^{6}$ Along similar lines, Charles Beard's Economic Interpretation of the Constitution became the lightning rod for a generation of constitutional scholars. Like Smith, Beard held that the delegates at the Constitutional Convention had protection of their interests and property in mind as they formed the new government. Economic motives, he argued, not political ideology, provided the impetus for political reform. Most importantly for the purposes of this thesis, Beard's "economic determinism" drew on Madison's "Tenth Federalist" for support, insuring the character of Madison

6 James Allen Smith, The Spirit of American Government (New York: MacMillian, 1907.) See Richard Hofstadter's, The Progressive Historians: Turner, Beard, Parrington (Chicago: University of Chicago Press, 1979), for an overview of the Progressive historians. 
would figure prominently in future debates over the Constitution .

Beard's work reopened interest in the Constitutional era and promoted--in particular through the controversy over economic determinism--new interpretations of Madison. One offspring of Beard was the pluralist view. With regards to interpretations of Madison, the pluralist perspective contains two different views, one negative and the other positive. In general both pluralist views hold that Madison recognized the diverse interests of American society, and actively incorporated them into the new Constitutional system. Pluralists differ, however, in regard to Madison's reasons for encouraging multiple interests to influence the new government. Positive pluralists maintain Madison wanted interest groups to participate directly in government and have a voice in the formation of policy. Negative pluralists argue that Madison formed a government in which different interests negated each other by design, allowing the colonial elite to govern with little interference.

From the turn of the century to the end of World War II, the works of Harold Laski, Harold Bentley, and Walter Lippman provide the best example of the former view, the positive pluralist interpretation. ${ }^{7}$ As Paul Bourke has

7 See Harold Laski, The Foundations of Sovereignty (New York: Books for Libraries Press, 1921, 1968); Walter Lippman, Public Opinion (New York: Free Press, 1922, 1949); and Arthur Bentley, Process of Government (Evanston, IL: the Principia Press of Illinois 1908, 1935). 
shown, this affirmative perception contrasted with Beardian interpretations in that they praised the founders for advancing their self interest. Commonly referred to as "interest group theorists, those who have pressed the "positive pluralist view" described Madison's "Tenth Federalist" as exhibiting an "essentially modern grasp of the group character of politics and of the play of organized groups on political institutions." ${ }^{8}$ In this view Madison was an ally of those looking to decentralize the authority of the political state, and distribute it among various interest groups.

In contrast, the negative pluralist view of Madison advanced a Beardian line. It regained prominence after World War II. Its foremost adherents were scholars such as James McGregor Burns, Robert Dahl, and Frank M. Coleman. They depicted the Constitution as an elitist document and maintained that Madison and his cohorts designed it to thwart majority rule through a scheme of checks and balances. ${ }^{9}$ Government under the new Constitution--as devised by Madison--sought to frustrate the will of the majority .

8 Paul F. Bourke, "The Pluralist Reading of James Madison's Tenth Federalist," Perspectives in American History, 9 (1975), 271-295, 273.

9 Consult Robert A. Dahl, A Preface to Democratic Theory (Chicago: University of Chicago Press, 1956); James McGregor Burns, Deadlock of Democracy (New York: McGraw Hill Book Co., 1971); and Frank M. Coleman, "The Hobbesian Basis of American Constitutionalism," Polity, 7.1 (1974), 57-89. 
Since World War II both pluralist visions of Madison and the founding era have drawn fire from scholars who downplay the role of interest in eighteenth century politics and emphasize, instead, ideological factors. The fifties-still the most noteworthy decade in terms of Madison scholarship--saw the brilliant work of Adrienne Koch, Irving Brant, Neal Riemer, Martin Diamond, and Douglas Adair. Adair, in a series of articles and an unpublished but often cited dissertation, argued that the ideology of the Scottish Enlightenment philosopher, David Hume, provided Madison with his ideas of faction and the extended republic. ${ }^{10}$ Brant, in his multi-volume biography of Madison, along with other works by Koch, Riemer, and Diamond, stressed Madison's commitment to representative government, implicitly drawing out the Lockean influences in his thought. ${ }^{11}$ From their works Madison emerged as more democratic, and the importance

10 Douglas Adair, "The Tenth Federalist Revisited," William and Mary Quarterly, 8.1 (January 1951), 467-487; and "That Politics May Be Reduced to Science: David Hume, James Madison, and the Tenth Federalist," Huntington Library Quarterly, 20.4 (August 1957), 343-360. These two articles are good summaries of Adair's theories concerning Madison's ideological influences.

11 Irving Brant, James Madison, 6 vols. (Indianapolis: Bobbs-Merrill, 1941-61.); Adrienne Koch, Jefferson and Madison: The Great Collaboration (New York: Alfred A. Knopf, 1950); Neal Riemer, "The Republicanism of James Madison," Political Science Quarterly, 69 (March 1954), 45-64; and "James Madison's Theory of the Self-Destructive Features of Republican Government," Ethics 65 (October 1954), 34-43; and Martin Diamond, "Democracy and The Federalist: A Reconsideration of the Framer's Intent," American Political Science Review, 53 (March 1959), 52-68. 
of political ideology to his thought appeared paramount.

During the late sixties and early seventies, however,

yet another paradigm of the founders' thought appeared, and interpretations of Madison underwent another revision. The classical republican revolution among American historians discarded economic and Lockean interpretations of the founding era, and instead argued for the primacy of English Opposition thought as the fuel which ignited the revolutionary fires of the eighteenth century. J.G.A. Pocock and Caroline Robbins traced the ancient, European, and English development of classical republican thought (or civic humanism) to America. Bernard Bailyn and Gordon Wood analyzed the transformation and manifestation of opposition thought in its American setting before and during the Revolutionary and founding periods. ${ }^{12}$

12 The literature produced by classical historians is voluminous. Some of the more important works are J.G.A. Pocock The Machiavellian Moment: Florentine Political Thought and the Atlantic Republican Tradition (Princeton: Princeton University Press, 1975; Caroline Robbins The Eighteenth-Century Commonwealth Man: Studies in the Transmission, Development, and Circumstance of Enqlish Liberal Thought From the Restoration Charles II until the War with the Thirteen Colonies (Cambridge: Harvard University Press, 1959); Bernard Bailyn The Ideological origins of the American Revolution (Cambridge: Harvard University Press, 1967); Gordon S. Wood The Creation of the American Republic, 1776-1787 (Chapel Hill: University of North Carolina Press, 1969); Lance Banning The Jeffersonian Persuasion: Evolution of a Party Ideology (Ithaca, N.Y.: Cornell University Press, 1978); Drew R. McCoy, The Elusive Republic: Political Economy in Jeffersonian America (Chapel Hill: University of North Carolina Press, 1980). Robert Shalhope has provided two historiographical analyses of republicanism in "Toward a Republican Synthesis: The Emergence of an Understanding of Republicanism in American 
Following the lead of Robbins, Pocock, Bailyn and Wood, other scholars who use the republican model interpreted Madison in new ways. Lance Banning, in The Jeffersonian Persuasion, depicted Madison as a quintessential classical republican. He saw the Jeffersonians as reacting to Federalist modernizing policies in much the same manner as had Radical whigs in seventeenth and eighteenth century England. Just as the Whigs, the so-called "Country" bloc, stubbornly resisted the English "Court" party's seventeenth century attempt to usher in a new, commercial society based on financial manipulation, so, according to Banning, did the Jeffersonians resent the development-minded policies of Alexander Hamilton. In each instance, English and American "country thinkers" saw their adversaries as innately corrupt.

Drew McCoy sketched an even clearer picture of Madison as a classical republican in the Elusive Republic. Studying Madison's political ideology, McCoy depicted Madison's support for an agrarian society as an attempt to expand across time rather than space. According to McCoy, Madison favored geographic expansion to slow America's progression toward a manufacturing society, anathema to classical republicans who viewed modernity as innately corrupt. To

Historiography," William and Mary Quarterly, 29.1 (January 1972), 49-80, and "Republicanism and Early American Historiography," William and Mary Quarterly, 39.2 (April 1982), 334-356. 
both Banning and McCoy, Madison was always looking backwards to find the true republican society. He fought to forestall the future. ${ }^{13}$ He feared change because it threatened to destroy the economic and political principles upon which the republic's security rested.

Like the Lockean and economic interpretations of the founding era, republican explanations stressed the dominance of one ideology. From 1968 to 1980 this view of eighteenth century American society--and of Madison--reigned supreme. Convincing challenges to this monolithic view appeared slowly and has left the historiography of Madison and the founding period in a state of flux.

Joyce Appleby first attacked the classical view of the founding period. Appleby refocused scholarly attention on a different set of principles: the liberal, Lockean, and Adam Smithian. She finds in these the heart of Jeffersonian ideology. Appleby undermined much of classical historiography by showing liberal ideas competed openly with Radical Whig paradigms in both seventeenth century England and late eighteenth century America. ${ }^{14}$ Yet unlike older pluralist interpretations, which used the concept of self interest to describe either a political attempt by a

13 See note 9 for bibliographical information on MCCoy's and Banning's monographs.

14 Joyce Appleby, Economic Thought and Ideology in Seventeenth Century England (Princeton: Princeton University Press, 1978); and Capitalism and the New Social Order (New York: New York University Press, 1984). 
colonial elite to thwart majority rule, or depicted the founders as advocating a modern concept of interest group politics, Appleby presented a broader and more egalitarian picture of liberalism. Echoing, and pushing beyond, Louis Hartz's Liberal Tradition in America she maintained that individualistic Lockean doctrines permeated the political, economic, and social structure of America in the 1790s. Jeffersonian liberalism, in Appleby's view, encouraged a democratic, informal type of politics open to all, not just a colonial elite. Jeffersonians, she continued, espoused a doctrine of rough equality, which in turn threatened a dominant colonial upper class, represented by the Federalists. Far from being a source of republican distrust and fear, Appleby showed that ideas of self interest, commerce, and prosperity swayed men of this time as much as republican ideas of virtue, frugality and self sufficiency. Appleby's Madison, therefore, appeared decidedly more modern, economically and politically, than did the Madison of McCoy or Banning.

Others have sided with Appleby. Isaac Kramnick has noted that eighteenth century republican ideology was not without competitors. He maintained that at least four different paradigms competed for supremacy during the formative years of the republic. Republican, liberal, work ethic Protestantism, and state centered theories of power and sovereignty proliferated and citizens easily interwove 
strands of each into their discourse. ${ }^{15}$

John Patrick Diggins, on the other hand, has classified the hunt for classical republican thought in eighteenth century America as a snipe hunt. ${ }^{16}$ According to Diggins, republican historians have mistaken Calvinistic doctrines for civic humanism because both stressed concern with the public good. For Diggins, the foundations of American society rested on Lockean and Calvinist principles. He held that republican scholars viewed the founding period as ideologically alienated from the present. A change of principles had transpired. They surmised, wrongly according to Diggins, that liberalism had, at some time, replaced republican principles as the guiding precepts of American society. He maintained that America seemed divorced from its original maxims because the crucial corrective to unfettered Lockean liberalism, Calvinism, had vanished from the American mind.

While Diggins deplored modern liberalism, he argued that its roots spring from a moral liberal tradition active in the Republic's early years. While Diggins stressed the dominance of liberal doctrines in American History, he interpreted Madison in a different manner. For all of his

15 Isaac Kramnick, "The 'Great National Discussion': The Discourse of Politics in 1787," William and Mary Quarterly, 45.1 (January 1988), 3-32.

16 John Patrick Diggins, The Lost Soul of American Politics: Virtue, self Interest, and the Foundations of Liberalism (New York: Basic Books, 1985). 
insistence on the presence of Calvinism during the Constitutional era, he imparted little of it to Madison's character. Following the older pluralist tradition in this instance, Diggins characterized Madison as anti-democratic, determined to use government to manipulate diverse interests, protect the wealthy, and frustrate the will of the majority. Diggins, in this instance, fell into a neoBeardian mindset, and thus explained Madison's motivation during the founding era as a plot to entrench the colonial aristocracy. Protection of economic power was his preeminent, if not only, goal. In this regard Diggins added the weight of his scholarship to an explanatory model of Madison which was already anchored in a mire of narrow interpretations.

With the notable exceptions of Kramnick and Appleby, twentieth century scholars described Madison through a singular paradigm, liberal or classical. Both arguments are valid in so far as they delineate aspects of Madison's ideology. Both err, however, in assuming the singularity of his mind.

As of yet no historian of the founding era has sought to understand the classical side of Madison while also taking into account the recent demonstration of competing ideological voices in eighteenth century America. This thesis argues that a fuller understanding of Madison is possible only by approaching his thought as sui generis and 
composed of an intermixture of both republican and liberal doctrines.

Here I analyze Madison from the Revolution to 1795. The dates correspond roughly to the time covered by the most recent edition of Madison's writings. ${ }^{17}$ Two important methodological premises deserve mention. First, in order to investigate the common assumption that Madison altered his ideology after 1788, his works before and after the Constitutional Convention demanded equal attention. ${ }^{18}$ Second, the research concentrated on Madison's private writings as much as his public ones. The greatest shortcoming of Madisonian scholarship is its reliance on the Federalist. A series of articles written during a partisan political struggle and under exacting time constraints, I hold, should not be made into the sole "authoritative" Madison text. For years scholars have interpreted Madison through his actions in 1787 and 1788. To the contrary, a

17 The completion of Madison's papers, previously under the editorship of Robert Rutland and presently J.C.A. Stagg, is underway.

18 A good example of this is exhibited by a recent exchange between two White House lawyers and Theodore Draper over the nature of executive power. In the article, the two legal counselors argue that Madison's true political beliefs were articulated at the Constitutional Convention and in the text of The Federalist. According to the two lawyers, Madison's later writings resulted from "purely political motives" dictated by his emergence as a Jeffersonian oppositional leader opposed to Federalist policies. His later writings, they hold, carry little validity when dealing with issues concerning the Constitution. Consult, "The Constitution in Danger," New York Review of Books, 37.8 (17 May 1990), 50-53. 
balanced account of Madison must grant as much authority to his private correspondence. While The Federalist is not excluded, it received less emphasis than tradition has previously demanded.

Three chapters comprise the heart of this thesis. Each explores a different side of Madison's thought. Chapter two examines the "classical" Madison through two different strains of republicanism prominent in his thought, the Radical Whig tradition and the writings of Montesquieu. Radical Whig and Montesquieuian republicanism are alike in some ways, and different in others. Both believed in the concept of virtue, and the need for a homogenous, stable population as essential to a republic. Yet, Radical Whig theory was concerned more with corruption and abuse of power. It had a more defined political program. Its adherents in the United States took on a character that rejected the balance of power theory and advocated legislative supremacy. Representatives were to be mirrors of the population they served, and hold office for short terms to avoid corruption and increase accountability. In contrast, Montesquieu's republicanism is more theoretical than pragmatic, and while concerned with abuse of power, did not exhibit the paranoid fear of power prominent among English Opposition thinkers such as Algernon Sidney, John Trenchard and Thomas Gordon. Montesquieu wrote of the general characteristics of republics and examined standard 
doctrines such as the balance of power. He was concerned as much, if not more, with the stability of the republic as with protecting it from pernicious forces.

Madison employed the philosophy of both republican views as ideological weapons to protect the new American republic. The first part of the chapter, on Madison and Radical Whiggery, reveals the paranoid Madison, one concerned continually with insidious political and religious plots designed to enslave Americans. The second half of the chapter probes Madison's conception of the Senate, to him the crucial vessel of virtue. He believed a properly constructed Senate represented the establishment of virtue within government. If Radical whig ideology protected society from detrimental internal and external threats, the Senate protected the stability of the new nation by acting with Montesquian coolness and reason. In Madison's mind, it was always attuned to the public good.

Chapter three turns to the "liberal" Madison. In it I seek to blunt the pluralist criticism of Madison. Pluralists who write in a Beardian vein have referred to Madison's doctrine of minority rights as proof of his complicity in plots to frustrate majority rule. His ardent support of property, they have held, also indicates his elitist tendencies. Yet, considered through his actions and other writings--that is his life outside The Eederalist--it seems clear that Madison held to a theory of property that 
was Lockean. Furthermore, Madison's well developed philosophy of minority rights displays a logical application of natural law to civil society. To Madison's mind, majority rule must reign supreme, but could never infringe natural rights. Subsequently, the individual and socially marginal groups--not the social elite of the colonies--found a champion in Madison.

The second half of the chapter revises conventional interpretations of Madison's theory of interest. Looking beyond The Federalist Papers reveals the lopsided view most scholars have taken towards Madison's doctrine of interest. Described in The Federalist Papers as a negative force, other evidence exists to show that for Madison interest advanced properly was not evil, but an important part of the process of discerning the public good.

Chapter four explores, through an analyses of Madison's political economy, what Isaac Kramnick referred to as "the profusion and confusion of political tongues among the founders."19 Madison's thought in this regard manifests a blending of classical and liberal tenets. While an advocate of free trade and the releasing of individual initiative, Madison also held to republican ideas which upheld the moral and political benefits of an agrarian society. No better example of the sui generis nature of Madison's thought

19 Isaac Kramnick, "The 'Great National Discussion': The Discourse of Politics in 1787," 4. 
exists than his political economy.

Explaining Madison through the lens of one ideology does injustice to one of the most profound American thinkers. Madison himself once noted "there is a middle way to be taken which corresponds at once with the theory of free government and the lessons of experience." 20 Scholars of Madison should heed his words. To adherents of the liberal and classical paradigms, Madison acted either solely out of self interest, or conducted himself in a selfless manner and expected the rest of society to adjust accordingly. The middle way is missing in most of their works, and it is time to describe Madison in the same terms that he used, three years before his death, to characterize the American system of government, "emphatically sui generis." 21

20 Marvin Meyers, The Mind of the Founder (Indianapolis: Bobbs-Merrill Company, 1973), Madison to John Brown, 12 October $1788,58$.

21 Madison to Daniel Webster, 15 March 1833, quoted in Drew McCoy, The Last of the Fathers, 149. 
CHAP TER II

THE CLASSICAL MADISON: TYRANNY AND VIRTUE

In a recent biography, Drew McCoy stressed the importance of republican ideology to Madison's thought, especially his ability to act in a cool, objective manner. Following McCoy's lead, this chapter explores the influence of classical republicanism on Madison's thought. While not arguing for an interpretation of Madison as solely classical, this chapter shows aspects of Madison's thought depended upon tenets of civic humanism. In particular, Madison's struggle for freedom of conscience has long been used to reveal the influence of Lockean principles. However, Madison's concern for religious freedom reveals more than a concern for civil rights. It also shows the influence of radical Whig ideology. Madison's fear of a political and religious conspiracy showed his persistent, and very republican, concern that a corrupted government could subvert liberty and lead to tyranny.

Furthermore, Madison's view of the senate coincided with classical descriptions of an upper-house. His description of the functions of the senate was similar to Montesquieu. The upper-house would use virtue to check faction. A virtuous senate combined with a citizenry imbued 
with republican values were key ingredients to keeping America stable and free. When Madison used republican language it habitually concerned protection of the republic. Historians now realize that Americans used the ideology of Radical Whiggery to grasp the significance of the acts initiated by the British Parliament following 1763 . These acts were not seen as prudent, moderate attempts to stabilize British finances. Colonists, rather, molded Whig ideology to their own circumstances, and viewed each act as a deliberate precedent setting measure of a corrupt and devious British monarchy intent on reducing the colonists to a state of dependence. Tyranny would replace liberty unless the colonists halted the process before their bonds rendered them unable to resist.

According to revolutionary thinkers who drew upon whig doctrines, a key conspirator in this plot to enslave the colonist was the Anglican church. Before 1763, suspicions of the church were widespread. Talk of establishing an episcopate in the colonies caused people to fear the church. Especially troublesome was the creation in 1701 of the Society for the Propagation of the Gospel, a branch of the Anglican church formed to evangelize native Americans. Many colonists believed its true aim consisted of a "formal design to root out Presbyterianism, etc., and to 
establishing both episcopacy and bishops."1 ${ }^{1}$ The events that transpired after 1763 convinced many colonists that the Anglican church threatened not only religious freedom, but was part of a larger British attempt to deprive Americans of their liberty. By 1765, many colonists assumed "the stamping of and episcopizing [of] our colonies were...only different branches of the same plan of power." 2 One of those men affected by this idea of a dual religiouspolitical conspiracy to subjugate Americans was James Madison. To paraphrase the remarks of J.G.A. Pocock, Madison, in opposing Anglican establishment, spoke the language of the country party (Radical Whiggery) and knew he spoke it. ${ }^{3}$

Madison's first public act showing his concern over British activities occurred during his days at the College of New Jersey (Princeton). He was an early and always prominent member of the American Whig society. In reality the club devoted most of its time to satiric (and sometimes obscene poems) aimed at the more piously minded Clios,

1 Jonathan Mayhew, "Observations on the Charter and Conduct of the Society for the Propagation of the Gospel in Foreign Parts," (Boston, 1763): 103-108. Quoted in Bernard Bailyn, Ideological Origins of the American Revolution, 96.

2 Alden Bradford, Memoir of the Life and Writings of Rev. Jonathan Mayhew (Boston, 1838), 372. Quoted in Ibid, 97.

3 J.G.A. Pocock, Machiavellian Moment, 529. Pocock's actual words are "The Jeffersonians spoke the language of the country and knew they spoke it." 
called Tories by Madison and friends because it proved the worst insult possible. While the club spent most of its time in social activities, the political connotations are evident from the names. The name "American Whig" referred in 1768 to the pen name of William Livingston, a man who had vigorously opposed an attempt by the Anglican church to strengthen church-state ties by creating an American episcopate. Members of the American Whig Society joined the club because they felt it offered a means to counter British attempts to establish a new set of royal church governors in the colonies. ${ }^{4}$

Madison, in joining the Whig club, revealed his opposition to the continued creation of offices in America for placemen, which he saw continuing the process of corruption. Customs enforcement offices created by the Townshend duties of 1770 , and the attempt to create more posts for clergymen, revealed the insidious plot by the crown to continue to take further political power from the assemblies, and religious freedom from all.

Madison's concern over a dual political and religious threat to liberty was fully apparent in a candid letter to his college alumnus, William Bradford, in 1774. Commenting on the Boston Tea Party, Madison declared that while

4 Irving Brant, James Madison, 1:84-86. Brant reveals that Livingston's fight over church state separation began in 1752 when he published the "Independent Reflector," in which he opposed using public funds to support a parochial school. 
Bostonians might have used more discretion, they had accomplished one important goal. Political and even military contests were needed to "instruct in the Art of defending Liberty and property." Madison felt the British assaults on the colonies, especially Boston, had a positive side in so far as the attacks stopped any notion of Anglican establishment in the northern colonies, an institution Madison himself suffered under in Virginia. Madison claimed that if the Anglicans had succeeded, "slavery and subjection would have been gradually insinuated among us." The problem resulted because established churches "tend to great ignorance and Corruption, all of which facilitate the Execution of mischievous Projects." 5

Madison here reiterated a common revolutionary whig theme. An established church becomes dangerous because it can be manipulated by individuals bent on tyranny. The King and his ministers were usually identified as instigators of this plot. Not surprisingly, Madison condemned in this same letter the "ministerialism" of Massachusetts Governor Hutchinson, whose patronage machine provided an obvious example to American Whigs of anti-republican corruption. Madison's fear of the Anglican church caused him to act in ways uncharacteristic of the future champion of civil and

${ }^{5}$ William T. Hutchinson and Robert A. Rutland, et.al., The Papers of James Madison, 15 vols. (Charlottesville, Va: University of Virginia Press, and Chicago: University of Chicago Press, 1962-1985), Madison to William Bradford, 24 January $1774,1: 105$. Hereafter cited as JM. 
religious rights. In June of 1775 the Continental Congress designated July 20 as a day of public fasting and prayer in order to bring King George to a "reasonable" state of mind. An Anglican parish priest, Madison informed a friend, refused to "observe the fast or preach on that day" pleading freedom of conscience. As a member of the orange county Committee of Safety, Madison participated in closing the church and stopping the minister's salary stopped. Indeed, if the man did not stop his insolence Madison warned that he might get "ducked in a coat of tar and surplus of feathers and then he may go... and act under the lawful authority of Genl. Gage." ${ }^{6}$ Three months earlier the committee had visited the rector of the church the Madisons attended. Reverend John Wingate apparently had possession of several pamphlets which condemned the actions of the Continental Congress. When the pastor refused to turn over the requested pamphlets, the group took the pamphlets, most likely by force, and burned them because they contained "the most imprudent falsehoods and malicious artifices..." designed to "excite divisions among the friends of America." 7 As for the author of the pamphlets, a New York Loyalist by the name of Rivington, Madison declared his wish

${ }^{6}$ JM, Madison to William Bradford, 28 July 1775, 1:161.

7 Irving Brant, James Madison. 1:162-63. The quote is from a declaration the Orange Committee of Safety issued before burning the pamphlets. Brant has "good reason to believe" Madison was the author. 
to have "Rivington and his ministerial gazetteers for 24 hours in this place. Execrable as their designs are, they would meet with adequate punishment," most likely tar and feathers, a favorite punishment of Madison at this time. ${ }^{8}$ Madison's intolerance of the Anglican clergy underscored his fear that the church remained a threat to American liberty. The work of corrupt men like Rivington and "his ministerial gazetteers" fostered disunion and hampered the colonists' attempt to stave off corruption. Madison would not concede the Anglicans' argument for "freedom of opinion," denouncing it as rhetoric used in the plot against liberty. What is unique about Madison's attitude and actions was the fact it aimed only at Anglicans, who in the colonies embodied "the wickedness of the present Ministry." "In contrast, he tolerated other religious sects who did not abide by the rules of the Continental Congress because they were not part of the plot to enslave the colonists.

In January of 1775 Madison contemplated the decision of Quakers not to sign the Continental Association. In a

8 Ibid., Madison to William Bradford, Early March 1775, 1:141. Madison's disposition to tar and feathers is quite evident in this letter. He contrasted the spirit of Virginians, who recently tarred and feathered a man who treated one of the members of the Committee with disrespect, with that of New York where Rivington and company operated with impunity.

JM, Madison to William Bradford, 20 January 1775, 
letter to William Bradford, the young Virginian remarked he could not "forbear suspecting them to be under the controul and direction" of the British, "for I take those of them that we have to be too honest and simple to have any sinister or secret Views..." While Madison did not think anything in the Association "inconsistent with their religious princli]ples," he respected their view. ${ }^{10}$ To him, the difference between the Quakers and Anglicans was that Quaker religious precepts were genuine, while the Anglicans used theirs to advance a "deliberate systematic plan of reducing us to slavery." ${ }^{11}$ Thus Madison was willing to grant Quakers the freedom of their convictions, despite his disagreement with them, while he denied the same rights to Anglicans, who, in his opinion, would use their freedom to subvert rather than nurture liberty.

Other aspects of Madison's thought during this time also testify to the influence of whig ideology, particularly the doctrine of precedence. Whig political theory stressed the deference of the people to their rulers. It stressed social stability, but by implying the people were normally docile whigs implied that they would revolt only when a true threat existed. To Madison, as to other Whig minded revolutionaries, the idea of precedence was all important,

10 Ibid., 135 .

11 Thomas Jefferson, "A Summary View," quoted in Gordon Wood, The Creation of the American Republic, 39. 
for if an act of the government caused strife among the people one could be sure a conspiracy against liberty existed. In turn, once sinister forces bent on enslavement of the citizenry became known, the people should "thus resist the forces of tyranny before they were actually enslaved."12 Whigs, therefore, scrupulously examined acts of government to see if any dangerous precedents existed, and then acted to extinguish the threat before it unfolded. The idea of opposing tyranny at its inception was evident in Madison the revolutionary. Madison chided his friend William Bradford in 1774 for the instructions given by the Pennsylvania Assembly to its delegates to the Continental Congress. Pennsylvania advised the delegates to avoid all preparations for conflict and instead wait for the Crown to come to its senses and repeal its "obnoxious" legislation. The Pennsylvanians, according to Madison, counted too heavily on the "generosity \& Justice of the Crown" to act in a way favorable to the colonies. Madison thought it prudent to begin defense preparations and let Parliament's reaction to the Congressional petitions decide whether to cease or continue. Delay on the colonies' part "emboldens our adversaries," he insisted, cooled the united passions of Americans against the British, and improved the schemes of "our... secret enemies to disseminate discord \& 37-39.

12 Gordon S. Wood, Creation of the American Republic, 
disunion."13 Madison, then, would not wait for the reply of the King. Only early preparation for conflict, not the King's good will, preserved liberty. Resting on one's laurels allowed the agents of tyranny time to hamstring liberty's defenders.

If Madison in this instance showed his concern with early organization to counter a conspiracy against liberty, he developed it and the idea of precedent to a fuller extent after the Revolution in his fight against religious establishment in Virginia. By 1785 Madison had served in the Virginia Council of state, the Virginia Constitutional Convention of 1776, the Virginia House of Delegates, and the Continental Congress. He was a seasoned politician, as he displayed in the 1784 session of the Virginia legislature. Before it came a measure to re-establish the Episcopal church. At the beginning of the session it appeared the bill would pass. Supporters of the measure also had a powerful figure, Patrick Henry, on their side. But by stalling Madison postponed a vote on establishment until the next session. He also artfully eliminated the threat of Henry. Madison appealed to his ambition and worked to elect him governor, eliminating the most important ally of

13 JM, Madison to William Bradford, 23 August 1774, 
establishment. ${ }^{14}$

By holding the bill over until the next session Madison believed opposition to establishment would appear. Many Virginians confirmed his opinion by removing many of its supporters in the 1785 elections. Even so two of his allies, George and Wilson Nicholaus, felt that more needed to be done to destroy the bill. The Nicholaus' urged Madison to write an appeal to the public, and he agreed. The result was his famous "Memorial and Remonstrance."15 Madison's work in this regard has long been hailed as evidence of his devotion to Lockean, natural, rights. What has been neglected is the extent to which Madison's essay also reflected classical sentiments. Madison's fear of tyranny, the machinations of a dual religious-political conspiracy, his concern for precedence, and the language he employed all displayed the influence of classical republicanism.

In the first section of the essay, Madison gave a concise and--and clearly Lockean--plea for the inalienable

14 Irving Brant, "Madison: On the Separation of Church and State," William and Mary Quarterly, 3rd Series, 8.1 (January 1951), 4-5.

15 The editors of the Madison Papers maintain that the impact of "Memorial and Remonstrance" on assessment was minimal. Less than one fifth of all Virginians who were recorded as protesting establishment signed Madison's treatise. 1,552 signed their approval of "Memorial and Remonstrance" while another tract opposed to the bill, "Teacher's of Christian Religion," garnered 4899 signatures. The greater significance of Madison's work lies in the extent to which it revealed his own philosophy. 
right of freedom of conscience. But, in addition, and most important in this regard, the second section of the essay developed the republican themes of corruption and tyranny inherent in the bill. With regards to the latter, Madison noted that the preservation of a free government required more than fidelity to the classical separation of governmental departments. Citizens devoted to republican rule must also prevent any branch of government from committing an even greater type of corruption. They must scrutinize the government's acts to insure that political power never destroyed "the great barrier which defends the rights of the people."16 Classical theory taught that corruption occurred whenever a branch of the government assumed responsibilities not delegated to it. As Montesquieu pointed out in The spirit of the Laws, once a republic is corrupted the community could not remedy any evils except "by removing the corruption and restoring lost principles."17 In typical Whig fashion, Madison grimly described the outcome if the "great barrier" was not reerected and government officials stopped from violating their "metes and bounds." Rulers guilty of such encroachments, he warned, threatened to become "Tyrants." $8: 299$.

${ }^{16}$ JM, "Memorial and Remonstrance," 20 June 1785,

17 Baron de Montesquieu, The Spirit of the Laws, ed. Franz Neumann, trans. Thomas Nugent 2 vols. (New York: Hafner Publishing, 1966), 1:8:12:117. This citation method refers to volume, book, section, and page number. 
"The people who submit to it...are slaves."18

The fear of tyranny, so pervasive in Whig pamphlets prior to the revolution, remained with Madison long after the struggle for independence. ${ }^{19}$ As Irving Brant has pointed out, the language used by Madison in "Memorial and Remonstrance" regarding tyranny and slavery did not consist of a figurative use of the symbols of force; rather these terms pointed back to the threat of British tyranny, which the colonists had thwarted only after a long and arduous struggle. ${ }^{20}$ Madison implored his readers to destroy establishment before chaos again engulfed the colonies. Always aware of his audience, Madison illuminated the consequences of tyranny in a form no Virginian could fail to miss. While they recognized the political "slavery" described by Whig ideology, Virginians experienced it intimately every day through the institution of chattel slavery. They knew better than anyone in the North the depths such bondage entailed.

In section eight of "Memorial and Remonstrance" Madison returned to, and underscored powerfully, his republican fear of tyranny. There he analyzed the influence ecclesiastical

\footnotetext{
$8: 299-3 \frac{\mathrm{JM}}{0 .}$

"Memorial and Remonstrance," 20 June 1785,
}

19 For an examination of the Revolutionary pamphlets see Bernard Bailyn, Pamphlets of the American Revolution, 4 vols. (Cambridge: Harvard University Press, 1965)

20 Irving Brant, "Madison: On the Separation of Church \& State," 10. 
establishments had on civil society and warned that as often as not they erected a spiritual tyranny on the ruins of civil authority. In most instances establishment upheld "the thrones of political authority." Rulers who wished to subvert public liberty "have found an established clergy convenient auxiliaries." 21 Establishment, then, had no merit whatsoever. It pointed to spiritual tyranny and political domination. In this case Madison referred his readers to history, and, most importantly to their Revolutionary memory of the Anglican Church taking part in the British scheme to enslave them.

The precedent of the bill for religious establishment also drew Madison's attention. In a letter to Jefferson in January of 1785, he confided that establishment proved obnoxious because of "its dishonorable principle and dangerous tendency." 22 The tendency or precedent of the bill called for quick action before the consequences could be felt. Whig ideology provided an ideological influence which led Madison to recognize and resist tyranny at its inception, and, in turn, he called on American citizens to do the same.

Section three of "Memorial and Remonstrance" focused on the need for early action against schemes of usurpation. In $8: 302$.

${ }^{21} \mathrm{JM}$, Memorial and Remonstrance," 20 June 1785 ,

22 Ibid., Madison to Thomas Jefferson, 9 January 1785, $8: 229$. 
it Madison declared that "it is proper to take alarm at the first experiment on our liberties." In addition, he insisted that "we hold this prudent jealously to be the first duty of Citizens, and one of the noblest characteristics of the late Revolution." The American revolutionaries "did not wait until usurped power had strengthened itself... and entangled the question in precedents." "We revere this lesson much too much to forget it." 23 Madison again referred his readers back to the Revolution, reminding them that successful struggles against tyranny resulted from those who anticipated the problem and eliminated it before precedents gave it the semblance of legality and tradition.

This, as Madison put it, "jealousy" of liberty was, to him, both a duty and a right fought for in the Revolution, one stamped deeply in the memory of every American. The lessons of the Revolution--here seen through the lens of English Opposition ideology--provided the key to resisting establishment.

With all of the above, however, Madison was not done drawing parallels between the Revolution and the present. In an offhand but recognizable reference, he underscored his point that the establishment of one sect could also lead to religious and political domination. The same authority 
"which can force a citizen to contribute three pence only of his property for the establishment of one religion, "Madison wrote, "may force him to conform to any other establishment in all cases whatsoever." 24 The importance of this phrase rests with the monetary sum Madison used. All those that had fought in the Revolution knew what he implied. The three pence tax referred to the 1773 tax on tea which triggered a series of events leading to the Boston Tea Party and, ultimately, revolution. ${ }^{25}$ Madison argued that establishment carried the same seeds of tyranny as the Tea Act, but was clothed in a different guise. He pointed out the precedent of this act, taken by itself, like the Tea Act, did not seem destructive. However, viewed in context both acts were part of a grand plot against liberty. Harkening his readers back to the Revolution, Madison again linked political and religious actions, reminding them that religion and politics were complementary bedfellows when used by those intent on tyranny. Establishment provided only one step toward subjugation, but an important one. America, Madison reminded his readers, owed its liberty to acting before it was too late.

Madison drew one more parallel to show the danger of establishment. The bill for establishment, "distant as it may be in its present form from the Inquisition, it differs

24 Ibid., $8: 300$.

25 Irving Brant, James Madison, 2:351. 
only in degree." 26 Madison again revealed his classical fear that one step of corruption would eventually lead to tyranny. Precedent here as well was important. The analogy Madison drew to show the possible consequences of the bill must have grabbed the attention of readers both for and against the measure. The terror of the Inquisition combined with the more recent hysteria over the Quebec Act, and the fear it generated for its supposed support of "popery," divulged Madison's deep concern about the bill. If any tyrant rivaled King George in the colonists mind, it was the Catholic Church. Madison painted a picture designed to shock in order to expose the threat present.

Was Madison guilty of using scare tactics? Perhaps, but the threat seemed real to him. He studied history and had lived through the events that sparked Revolution. Moreover, he matured as an adult and began his political career at a time when Whig ideology, characterized by a paranoid fear of tyranny, corruption, and conspiracy, held sway over many Americans. Madison, moreover, had picked the right time to act like a paranoid Whig. Irving Brant has remarked that "Memorial and Remonstrance" was Madison's greatest contribution to religious liberty. According to Brant, Madison looked beyond a "seemingly trivial levy in aid of religious teachers, and saw its ultimate consequence 
in the denial of liberty and imposition of clerical control upon the state."27 A true Whig in this respect, Madison judged the legislation not only by its immediate impact, but also by its ends, asking how it endangered liberty.

The fear of conspiratorial plots against liberty never left Madison's mind. Not surprisingly, during the bitter party feuds of the 1790s, one finds Madison describing the Federalists as "Anglicans." 28 He reminded his readers which party carried the ideals of the Revolution, the Jeffersonians. "They have maintained...a deep conviction of the danger to liberty and Constitution... and have sometimes been reprehended in debate for an excess of caution and jealousy." 29 The diligent guard needed to uncover new plots against liberty should never be relaxed. Americans, who had the good fortune to possess the "inestimatable blessing of a free and defined constitution cannot be too watchful, nor too critical in tracing the consequences of new principles...that may remove the landmarks of power." 30 The fear of tyranny via religious bodies also remained uppermost in Madison's mind. While he understood that

27 Irving Brant, James Madison, 2:351.

${ }^{28} \mathrm{JM}$, Madison to Thomas Jefferson, 2 september, 1793, $15: 92-93$.

29 Marvin Meyers, The Mind of the Founder: Sources of the Political Thought of James Madison, "Political Observations," 20 April 1795, 287.

30 Ibid., "Letters of Helvidius," Gazette of the United States, No.4, 14 September 1793, 274. 
corruption of political power could appear at any time, he also held that too little political authority proved as great a vice as too much. ${ }^{31}$ With regard to religion, however, he never changed. While some political power was necessary for popular government, religion to his mind should never gain coercive power. In his "Essay on Monopolies," ${ }^{32}$ Madison reiterated his belief in keeping religious bodies from any kind of political power and maintaining a diligent watch for the first signs of tyranny. Referring again to the Tea Act of 1773, Madison maintained that Americans "owe their independence and their liberty to the wisdom of descrying in the minute tax of three pence on tea, the magnitude of the evil comprised in the precedent." The threat of tyranny would always exist, and citizens would be wise to guard "against silent accumulations and encroachments by ecclesiastical bodies." Madison then emphasized that examples of such encroachment "may be illustrated by precedents already furnished in their [the United States] short history." ${ }^{33}$ Failure to keep religion 1788,208 .

${ }^{31}$ Ibid., James Madison to Thomas Jefferson, 17 October

32 The correct title for the article is "Monopolies, Perpetuities, Corporations, Ecclesiastic Endowments." I have chosen to use it by the abbreviated name Brant employed for the sake of brevity. Hereafter it will be cited as "Essay on Monopolies." See the following footnote for bibliographical information.

33 James Madison, "Essay on Monopolies," quoted in Irving Brant, "Madison: On Separation of Church and State,", 21-22. 
out of government destroyed the "great barrier" that kept spiritual tyranny shackled. Crevices would appear, "through which bigotry may introduce persecution; a monster that feeding and thriving on its own venom gradually swells to a size and strength overwhelming all laws divine \& human." ${ }^{34}$ A vivid picture of tyranny, complete tyranny, Madison painted once more. Although known for his reserved manner, the subject of tyranny led him to reveal his inner emotions more deeply than any other.

In his opposition to ecclesiastical establishment Madison showed that protection of conscience required, for him, republican vigilance. Republican doctrine stressed the endless diligence of citizens watching for acts that usurped power or created dangerous tendencies that led to subjugation. This fear of tyranny bordered on obsession for some Radical Whigs. Madison, in this respect, stands fully in the classical tradition. Whatever inconsistencies may be found in Madison in other regards, there was none in his fear of, and opposition to political and religious oppression.

Madison's fear of tyranny revealed one aspect of his classical philosophy, that of Radical Whiggery; yet in a different way so does his view of the senate. The ideological influence that shaped his perception of the

34 James Madison, "Essay on Monopolies," quoted in Irving Brant, James Madison, 2:355. 
Senate did not draw on English Opposition thought. Madison regarded the senate as the bastion of wisdom, stability, reason, and virtue. In this sense he drew on Montesquieu as well as Enlightenment philosophy which stressed the role of reason.

Pluralist scholars, and more generally, historians who employ the liberal paradigm to describe the founding periods tend to view the Constitution and James Madison as instrumental in destroying the need for virtue in republican government. According to this line of reasoning, Madison's genius existed in constructing a popular government that thrived in a society dominated by interests. Virtue had no place in the new government, and Madison's mentioning, in one letter, of the need for virtue, one historian has passed off as a "moment of anxiety." 35

Gary Wills, however, has correctly pointed out that this kind of reading is much too selective. ${ }^{36}$ Any interpretation that paints Madison as discounting the need for virtue fails to consider the values and roles he assigned to the Senate. Like Montesquieu, Madison saw the need for virtue in government.

Montesquieu, in The spirit of the Laws, considered it a

35 John Diggins, The Lost Soul of American Politics: Virtue, Self Interest, and the Foundations of Liberalism, 68 .

36 Gary Wills, Explaining America: The Federalist, (New York: Penguin Books, 1981), 189. Wills refered, in this instance, to Robert Dahl's Deadlock of Democracy. 
maxim of republican government that the divisions of land should be equal and small. ${ }^{37}$ The theorist realized, however, "an equal division of lands cannot be established in all democracies." Circumstances would arise which would make an equal division of land impracticable, dangerous, "and even subversive of the constitution." "If it appears that this division of lands, which was designed to preserve the people's morals, does not suit the democracy, recourse must be made to other methods." ${ }^{38}$ Montesquieu solved this difficult question by recommending the creation of a senate. The great theorist saw the senate as a permanent body "to which years, virtue, gravity, and eminent service procure admittance." ${ }^{39}$ Because of their concern for the public good, Senators would provide a role model for citizens, and inspire the sentiments of virtue within the citizens. Because of the admirable qualities and stability they gave to government, Montesquieu advocated electing Senators for life. ${ }^{40}$

While Madison rejected Montesquieu's theories about republics existing in small areas and consisting of a homogenous population, his understanding of the senate's role paralleled the French thinker's in important ways.

37 Montesquieu, The Spirit of the Laws, $1: 2: 6: 45$.

38 Ibid., $1: 2: 7: 47$.

39 Ibid., $1: 2: 7: 47$.

40 Ibid., $1: 2: 7: 48$. 
First he expounded on Montesquieu's idea that an equal division of property was not possible in some popular governments. Madison believed such a division impossible; indeed the most "common and durable source of factions has been the verious [sic] and unequal distribution of property." 41 The distinctive feature of the senate, however, stemmed from its ability to proceed "with more coolness, with more system, and with more wisdom..."42 In a society prone to faction, a wise and virtuous senate advanced the public good. ${ }^{43}$

41 The Federalist Papers, (New York: Mentor Books, 1961), 10: 19. This method refers to the appropriate number and page.

42 James Madison, Notes of Debates in the Federal Convention of 1787 (New York: W.W. Norton, 1966), 83. Hereafter cited as Notes.

43 See Neal Riemer, James Madison: Creating the American Constitution (washington D.C.: Congressional Quarterly Inc, 1986), 121. Riemer sees the importance of the Senate in Madison's thought, but does not trace the possible ideological influences or elaborate in much detail on the subject. Jack Rakove's "Madisonian Moment," University of Chicago Law Review, 55.2 (Spring 1988): 473505, also points to Madison describing the senate advancing the public good. However, Rakove feels the ideological origins of such thoughts are Burkean. Ibid., 483. I find no evidence in Madison's writings to support such a theory. The case for Montesquieu seems more plausible to me. During his preparatory schooling under Donald Robertson before entering Princeton, Madison had access to Montesquieu's Spirit of the Laws, and probably gained his initial acquaintance with the author there. See JM, Editorial Note, 1:5, and Irving Brant, James Madison, 1:59. While at Princeton, Madison also came into contact with Montesquieu. President John Witherspoon used The Spirit of the Laws as a textbook. See Irving Brant, James Madison, 1:76. In addition, Burke is mentioned only once in Madison's writings, and that occurred when Madison, as part of a Congressional Committee to compile a bibliography for a 
In 1785, Madison responded to a letter from Caleb Wallace asking for help in forming the constitution for the future state of Kentucky. Madison's first words of advice dealt with the Legislative branch and the importance of the Senate. "By all means" one should include "a senate constituted on such principles as will give wisdom and steadiness to legislation." ${ }^{44}$ The senate must watch over the "aggregate interests" of the entire community. Madison's belief that a properly constituted senate would act for the common good was so strong he originally suggested that the veto power over the state legislatures be lodged in the Senate, not the executive. ${ }^{45}$ Can it be coincidence that the last words of Madison-Publius concerned the Senate? Madison argued in Federalist 63 that the utility and authority of the senate would stem from "such a display of enlightened policy and attachment to the public good, as will divide that branch of [the] legislature the affections and support of the entire body of the people."46 Like Montesquieu, Madison believed that the Senate's actions

possible library for Congress, cited Burke's Annual Register. When Madison specified men of authority, only Locke appeared above Montesquieu in the number of times cited. No one else is cited even half as many times as these two.

44 JM, Madison to Caleb Wallace, 23 August 1785, 8:350.

45 See JM, Madison to Edmund Randolph, 7 April 1787, 9:370, and Madison to George Washington, 16 April 1787, $9: 384$.

46 The Federalist Papers, 63: 390. 
would command the people's respect, and thus foster virtue within the people by example.

The need for a disinterested body devoted to the public good originated in Madison's mind in the 1780 s when he served in both the Continental Congress and Virginia House of Delegates. Madison despised the overriding concern with local interests when trying to legislate for the entire nation. Before the Constitutional Convention he confided to Edmund Randolph that he hoped local prejudices would have no place in the formation of the new government. ${ }^{47}$ The JayGardoqui talks of 1786 had impressed Madison for their lack of "just and extended maxims of policy," which promoted the prosperity of the Union, and the "predominance of temporary and partial interests" which attempted to give up the right of navigation on the Mississippi. ${ }^{48}$ State representatives, furthermore, frequently displayed the character of partisans for their respective states rather than "impartial guardians of a common interest." ${ }^{49}$ Particularly singled out for criticism by Madison were supporters of paper money schemes. Such men seemed unconcerned with the long term effects of legislative measures. "Is it to be imagined that an ordinary citizen or even assemblyman of Rhode Island in

47 JM, Madison to Edmund Randolph, 8 April 1787, 8:369.

48 Ibid., Madison to James Monroe, 5 October 1786, $9: 141$.

49 The Federalist Papers, 46: 296-297. 
estimating the policy of paper money ever considered or cared, in what light the measure would be viewed in France or Holland; or even in Massachusetts or Connecticut." 50 The need for an enlightened body was clear to Madison. The question was how to construct a senate so that cosmopolitan, dispassionate legislators capable of "discerning the true public good" won election. ${ }^{51}$

An effective remedy for removing men of narrow or local prejudices consisted of "process of elections as will most certainly extract from the mass of society the purest and noblest characters."52 Madison favored picking Senators by the people at large, or by the creation of large interstate districts. ${ }^{53}$ Such a method made it difficult "for unworthy candidates to practice with success the vicious arts by which elections are too often carried." ${ }^{54}$ The larger the district, the more interests within that district, the less

50 Marvin Meyers, The Mind of the Founder, "Vices of the Political System of the United States," April 1787, 90.

51 Jack Rakove, "Madisonian Moment," 482.

52 Marvin Meyers, The Mind of the Founder, "Vices of the Political System of the United States," April 1787, 91.

53 In the Virginia Plan, Madison originally called for the election of Senators by the House. However, once the convention began he quickly shifted to favor election by the people at large or by large interstate districts. Either he had not convinced himself of the efficacy of such a plan, or the idea was not Madison's originally. Brant felt Madison switched his position because election by the people would give Senators more independence. See Irving Brant, James Madison, 3:80. 
chance there was of an elected official representing one interest winning election. ${ }^{55}$ Election by district increased the odds that local, demagogic senators would gain office and pursue only the narrow interests of the constituency they represented. They lost sight of the aggregate good of the community. Madison, therefore, criticized Jefferson's "Notes on Virginia" in 1788 for advocating election of Senators by district. ${ }^{56}$ To impress upon senators the need to focus their attention on the general interests of all, Madison felt a process of elections in which the entire citizenry of the state voted for their senators proved best. ${ }^{57}$

In this vein Jack Rakove has argued that Madison's ideal senate was to be elected by constituencies sufficiently large to erase any degree of electoral accountability. ${ }^{58}$ While Rakove exaggerated in saying Madison wanted senators to be free of accountability, he touched on an aspect of the Senate Madison thought important, a method of election designed to pick virtuous men, who also had a measure of independence accorded them in

55 See The Federalist Papers, 10:83, for a concise summary of Madison's theory of representation.

56 Robert J. Morgan, "Madison's Theory of Representation in the Tenth Federalist," Journal of Politic.s, 36.4 (1974): 852-888, 863.

57 Marvin Meyers, The Mind of the Founder, "Critique of Jefferson's Notes on Virginia," October 1788, 57.

58 Jack Rakove, "Madisonian Moment," 482. 
order to promote the public good.

Independence for senators meant they could act as disinterested legislators. Madison confided to Edmund Pendleton in October, 1788, that some degree of impartiality must exist in even despotic governments. In Republics, however, impartiality "may be considered as the vital principle of the Administration." 59 Impartiality meant exercising independent judgment. It seems ironic, then, that Madison failed to get elected to the Senate because he possessed the very trait he expected members of the upper House to exhibit. Patrick Henry, still smarting from his defeat in the Virginia Constitutional Convention, kept Madison out of the Senate by spreading the rumors that Madison would not obey state legislative instructions. ${ }^{60}$

To Madison longer terms for Senators contributed to their freedom of action, but more importantly they furnished

\section{$11: 306$. \\ 59 JM, Madison to Edmund Pendleton, 20 October 1788,}

60 JM, George Lee Turberville to James Madison, 10 November 1788, 11:339. Madison was well aware that Henry's influence would keep him out of the Senate. In a November 2, 1788, letter to Edmund Randolph, Madison tells Randolph he would prefer to serve in the House. The senate was out of the question due to Henry's dislike of him. JM, 11:329. Henry, however, had good reason to make such accusations of Madison. In 1783 Virginia had withdrawn its support of the five percent impost bill. Madison, then serving in the Continental Congress, continued to support the measure. While torn by his decision, Madison felt, ultimately, his allegiance to the public good and his own conscience must overcome his fidelity to Virginia. He would risk his political career to stand for a measure he felt essential to the welfare of the nation. JM, Notes on Debates, 28 January 1783,147 . 
the means to consider long term national goals. Six year terms, he observed, permitted the senate to enact measures "which have a gradual and perhaps unobserved operation." Such measures were critical, in Madison's mind, for the general welfare of any society. The House, by contrast, consisted of members elected for terms so short that they proved "unable to provide more than one or two links in a chain of measures, on which the general welfare may essentially depend." Li Longer terms provided continuity to legislation some continuity, and also pointed to a feature of the Senate that Madison felt America needed most, stability.

By 1787 Madison felt that the colonies stood on the brink of dissolution. Inadequate government financing, paper money schemes, inter-state commercial struggles, and Shays' Rebellion, fueled Madison's concern for the state of the Union. ${ }^{62}$ Even Congress came in for its share of criticism. In 1783 he watched with distaste the antics of new Congressmen in a minor debate over consular power. In the end nothing was resolved, which caused Madison to write that experience "constantly teaches" that new members of a public body failed to act with the proper respect towards

\footnotetext{
61 The Federalist Papers, $63: 383$.

62 For a good discussion on Madison's fear of disunion, consult the third chapter of Neal Riemer's James Madison: Creating the American Constitution.
} 
the acts of their predecessors. Members had not studied the issues or become acquainted with present circumstances, a grievous sin in Madison's eyes. ${ }^{63}$ He concluded that a change of legislative "members \& circumstances often proves fatal to the consistency and stability of public measures." 64 In an insightful exchange of letters with Philip Mazzei in 1788, Madison defended the Constitution because it supplied steadiness. Stunned by Mazzei's implication in an earlier letter that his support of the Constitution was anti-republican, Madison fired back that "experience has proved that the real danger to America \& liberty lies in the defect of energy and stability in the present establishments of the United States." 65 Obviously, then, by the time of the Constitutional Convention Madison thought it vital "that a stable and firm Government,

63 Madison, by contrast, during his first six months in Congress made no motions and "probably never entered a debate." Lance Banning, "James Madison and the Nationalists," William and Mary Quarterly, 40.2 (April 1983), 230. Madison's reason for keeping such a low profile probably stemmed from his natural shyness, weak voice, and his tendency not to enter into a fracas until he had prepared himself adequately.

64 JM, Notes, 6 January 1783, 6:16. Madison reiterated these same thoughts in The Federalist Papers, 62:188.

65 JM, Madison to Philip Mazzei, 8 October 1788, $11: 278$. Madison went on in his letter to say that he understood why Mazzei felt as he did. The Frenchman labored under a system in which there was too much government, while the opposite had proved true for Madison. Madison concluded by saying that both he and Mazzei would feel differently if each exchanged places with the other. 
organized in the republican form," be constructed. ${ }^{66}$

The Upper House provided Madison the governmental stability he sought. "The senate was to commonwealth what ballast is to a ship."67 "One great end" of the senate was, "that being a firm, wise, and impartial body," it would give "stability to the General Government in its operation on individuals." 68 By giving "that stability which was called for everywhere," Americans could rebuke "Enemies of the Republican form," who alleged that steadiness in government was contrary to the nature of republicanism. ${ }^{69}$ Not surprisingly, then, Madison advocated long terms for Senators. He hinted that even a nine year term might not prove too long and supported seven years with some reservations. Madison worried that a seven year term for Senators would still leave that branch impotent in the face of the more numerous House. ${ }^{70}$

A chronic worrier, Madison obviously overreacted to the lack of stability in America. In this instance, his determination to endow the senate with stability drew him away from the suppositions of Radical Whiggery, which

${ }^{66}$ James Madison, Notes, 12 June 1787, 110.

67 Alexander Hamilton, Pay Book of the State Company of Artillery, 1777. Quoted in Gordon S. Wood, The Creation of the American Republic, 1776-1787, 210.

68 James Madison, Notes, 26 June 1787, 199.

69 Ibid., 12 June 1787, 110-111.

70 Irving Brant, James Madison, 3:48. 
stressed rotation in office and short terms in order to guarantee the renewal of virtue. ${ }^{71}$ In this sense he looked to the other, Montesquieuian, side of classical republicanism. Madison, like Montesquieu, required the presence of a wise and virtuous senate to balance both government and community.

If virtue and stability emanated from the second house of the legislative body, Madison expected one more quality to characterize the Senate's action. Virtue by itself was not enough. Madison was a philosopher, as Adrienne Koch has put it, "perhaps the best this nation has ever produced." 72 Living in the era of the American Enlightenment, Madison looked to the Senate to provide reason and systematic study of legislation. Virtue and stability had to be tied to the means best capable of achieving them, wisdom.

As the stronghold of reason the senate could offer guidance that both the people and government, at times, lacked. Although the American people "are an enlightened and liberal people...they are not all philosophers."73 Gary Wills has also pointed out that Madison accepted the distinctions between heart and head, which appeared in the

71 J.G.A. Pocock, Machiavellian Moment, 519.

72 Adrienne Koch, Jefferson and Madison: The Great Collaboration (London: Oxford University Press, 1973, reprint of 1950 edition by Alfred A. Knopf), 291. $11: 278$.

73 JM, Madison to Philip Mazzei, 8 October 1788, 
Federalist. ${ }^{74}$ State legislatures, had, at times, good intentions, but failed to convert them into coherent policies. Good government meant devotion to the public good, but also to "a knowledge by which that object [the public good] can be best attained." Americans, according to Madison had paid "too little attention" to this important principle. ${ }^{75}$

Madison's language revealed constantly the necessity of linking virtue and wisdom. Whenever Madison talked about the senate, usually wisdom or some other synonym for it appears first. Use of reason, however, also consisted of proceeding in a detached, scientific manner. Madison, then, described members of the upper house as acting with "more coolness and system" to him the senate was a "temperate and respectable" body. ${ }^{76}$ Led by no permanent interest, Senators could devote themselves to the study of law and "the affairs and comprehensive interests of their country."77 Dedicated to securing reason a place in government, Madison's thought did not differ from the prominent ideological understanding of human powers of his time. While rationality was supposed to reign supreme over

74 Gary Wills, Explaining America: The Federalist, 186.

75 The Federalist Papers, $62: 187$.

76 James Madison, Notes, 7 June 1787, 83, and The Federalist Papers, $63: 384$.

77 The Federalist Papers, $62: 379$. 
the passions, self interest led men to act in ways contrary to reason. ${ }^{78}$ Naturally, Madison looked favorably on that institution which subjugated interest to reason.

Madison favored, therefore, Senatorial appointment of judges because that body would use their "deliberate judgement."79 Both in the Constitutional Convention and The Federalist, Madison pointed to the salutary check the Senate could impose on "impetuous" legislation and the rash acts of the people. ${ }^{80}$ As he noted in The Federalist, the Senate would "suspend the blow the people aimed at themselves until reason, justice, and truth can retain authority." Their deliberate manner would allow them to "escape a variety of errors in the exercise of the legislative trust." ${ }^{81}$ Also significant for Madison was the Senate's ability to throw their weight to the side of justice to prevent the majority from endangering the fundamental rights of minorities. ${ }^{82}$ Finally the senate was to serve as a watchdog over government. It was to guard

78 Daniel $W$. Howe, "The Political Psychology of The Federalist," William and Mary Quarterly, 44.3, (July 1987): 485-509, 487-491.

79 James Madison, Notes, 5 June $1787,68$.

80 Ibid., 83.

81 The Federalist Papers, 63:383-384. See also James Madison, Notes, 26 June 1787, 193.

82 James Madison, Notes, 26 June 1787, 194-195. 
against governmental tyranny. ${ }^{83}$ The senate, then, enhanced the common interest of all by acting deliberately, and by ensuring the legislative process remained true to the principles of justice.

Such was Madison's theoretical picture of the senate, stable, dedicated to the public good, and possessing the intellectual qualities necessary for discerning and acting to promote the aggregate good of all. However, much to Madison's chagrin, the Senate's actions under the Constitution showed quickly that it could act in an unvirtuous manner, yet he held fast to his original conception of that body.

This became apparent to Madison in 1789, as took part in the debate over the proper titles for the President and Vice-President that Senator (and former Anti-Federalist) Richard Henry Lee initiated in the upper body's first session. Madison recoiled against the pompous titles Lee favored. They diminished the "true dignity" of both Washington and republican government. ${ }^{84}$ A similar controversy recurred in 1790 when the senate considered a

83 For a concise and persuasive article on the senate's utility as a check against governmental tyranny, consult George Carey, "Separation of Powers \& the Madisonian Model: A Reply to the Critics," American Political Science Review, 72 (March 1978): 151-164.

84 James Madison, Congressional Speech, quoted in Adrienne Koch, Jefferson and Madison, 102. 
bill which attached the title of "honorable" to Senators. ${ }^{85}$ Here, Madison believed, the senate threatened to inflict "a deep wound to our infant government." ${ }^{86}$ Madison had to endure more actions he thought betrayed the essence of that institution. The senate was directly responsible for twice defeating his bills of commercial discrimination in 1789 and 1794, measures whose passage Madison considered critical to the welfare of the nation. The senate, furthermore, originated the hated Bank bill and passed the bill on Assumption. Yet despite the empirical evidence that spoke to the contrary, and the fact that locally oriented state legislators elected Senators, Madison continued to hold to his original theoretical conception of the Upper House. ${ }^{87}$

The persistence of Madison's conception of the Senate as the vessel of virtue is evident from his acts during the first year of the new government. In the fight over pay differentiation between senate and House during the first

${ }^{85}$ JM, Madison to William Short, 6 April 1790, 11:140.

86 James Madison to Thomas Jefferson, 9 May 1789, quoted in Irving Brant's James Madison, 3:256.

${ }^{87}$ The evidence in the next paragraph of the text contradicts Rakove's assertion that with the election of Senators by state legislators went Madison's hope for the choosing of wise and virtuous men to fill the upper house. See Jack Rakove's "Madisonian Moment," 484. For an opinion that argues that the Constitutional Convention convinced Madison of the validity of a federal influence in Congress, see Lance Banning's "The Practical Sphere of a Republic," especially 183-187, in Richard Beeman, ed., et al. Beyond Confederation: Origins of the Constitution and American National Identity (Chapel Hill, N.C.: University of North Carolina Press, 1987): 162-187. 
session of Congress in 1789, Madison supported paying the former a slightly higher salary. He supported this hopeless motion, moreover, during his time as a member of the House. A difference in pay, Madison reminded House members during a July 1789 speech, would recruit for the senate "men of abilities and firm principles." Such men needed prompting so that they may be "induced to devote the experience of years, and the acquisitions of study, to the service of their country." ${ }^{88}$ Madison re-iterated these same thoughts in a letter to Wilson Cary Nicholaus. Pay discrimination needed to become a reality because the "utility of the Senate will depend on its being composed of the first characters." ${ }^{89}$ Three years later in 1792, amidst bitter political feuding, Madison found himself attacked in an anonymous pamphlet for his support of the pay discrimination between House and Senate members. Irritated, he replied in "Notes on Politics \& Views" that rewards for public service should be in proportion to the private sacrifices. No man, Madison maintained, should hang his head over supporting pay discrimination. "The utility of the senate will depend on the respectability of its characters." 90 Four years after passage of the Constitution, and now finding himself firmly

${ }^{88} \mathrm{JM}$, Congressional Speech, $16 \mathrm{July} 1789,12: 293$.

89 Ibid., Madison to Wilson Cary Nicholaus, 18 June 1789, 12:295. Emphasis in the original. $14: 399$.

90 Ibid., Notes on Politics \& Views, 4 November 1792, 
allied with Jefferson, Madison still clung to his vision of a respectable, educated, and experienced senate advancing the public interest.

Madison's stubborn insistence that wise and virtuous men existed and would make their way into the Senate was echoed by many other revolutionaries versed in classical theory. These men were confident there existed in the community a "senatorial part," a natural and intellectual elite that could govern in the interests of all. ${ }^{91}$ The idea that Madison discarded classical ideology with its emphasis on virtue fails as soon as one starts to examine his views on government. Virtue and wisdom were the fundamental qualities Madison prescribed for a united and stable United States. While the mass of society could not always be expected to act virtuously, Madison, like Montesquieu, clearly expected the Senate to behave in a manner that demonstrated its devotion to the public good. Yet if Madison imparted a classical understanding of the need for virtue in government, he also displayed a radical Whig mentality which stressed the importance of republican jealousy. This paranoid mentality, frequently concerned with threats to liberty both religious and governmental, formed an essential part of Madison's ideological character. Diligent attention, he believed

91 Gordon S. Wood, Creation of the American Republici $1776-1787,209$. 
fervently, must be paid to government's action in order to spot early signs of tyrannical corruption. Once detected, citizens must stifle such tendencies at their advent. Such qualities seemed necessary in Madison's eyes for the Republic's preservation. To overlook or discount the classical Madison is to miss an important aspect of his thought. 
THE LIBERAL MADISON: NATURAL RIGHTS AND INTEREST

The importance of republican ideology in Madison's thought has now gained legitimacy in historiographical circles, due in large part to the diligence of Lance Banning and Drew McCoy. Similarly, Stephen Watts' recent study on liberalism and republicanism in the early republic depicts Madison "as an ideological shaper of Jeffersonian Republicanism." 1 Yet to describe Madison solely through republican eyes misses the liberal aspect of his thought. Radical Whig and Montesquieuian republicanism can be described as Madison's means to protect the republic, but Lockean principles constituted his end. Republican principles and institutions were, for Madison, guardians of natural rights. Thus, as important as his republican principles were, alone they do not fully capture his thought. Equally important was the liberal side of Madison' mind. Although the subject of considerable study, the liberal Madison remains misunderstood.

Conventional liberal interpretations search for Madison's liberal principles in The Federalist. His

1 Stephen Watts, The Republic Reborn: War in the Making of Liberal America, 1790-1820 (Baltimore: John Hopkins University, 1987), 311 . 
masterful extended republic theory, found in the tenth paper, described how the size of the country bred a multiplicity of interests, which in turn allowed for their negation, insuring that no interest could arise to control government. ${ }^{2}$ In this regard, Madison-Publius described interest in a negative way. Yet Madison's other writings-indeed a multitude of them--insisted that promotion of interest was far from evil, showing the skewed and shallow historical understanding of Madison's theory of interest needs correction.

Another prominent view of Madison describes him as an elitist who helped design a system of government to protect the propertied elite from majority rule. Scholars such as John Patrick Diggins are especially critical of Madison's defense of property and minority rights. However, a thorough and broad study of Madison's theories of property and minority rights discloses that his dedication to such principles extended far beyond protecting the property of wealthy Americans. In fact, his theories in this matter encompassed a broad range of minority groups outside of the elite classes. Madison's defense of property and minority rights went much further than the preservation of the

2 For an extended analysis of faction and the extended republic, see Neal Riemer's James Madison: Creating the American Constitution, chapter five; and Jack Rakove's "James Madison and the Extended Republic: Theory and Practice in American Politics," This Constitution, 3 (1984): 16-22. 
colonial social hierarchy. His defense in this matter demonstrated a logical application of natural law to civil society. For Madison, majority rule was the pivot upon which republican government turned. As Drew McCoy has correctly observed, Madison's "preoccupation with the perils of majority rule must not be confused with a rejection of the principle itself." ${ }^{3}$ Madison's goals in 1787 and at the end of his life remained the same, "minimizing the risk of majority rule without abandoning the cause" of the system that was "the least flawed," popular government. ${ }^{4}$ Yet true to Lockean doctrine, he maintained that a government based on majority rule could never violate natural rights. To this end, no one worked harder than Madison to secure individual rights, especially the right of conscience, and elevate them to the same sacred plane as property. Furthermore, when Madison put into practice his theory of protecting minorities, he did not work to promote the upper classes. On the contrary, he labored to protect the nation's religious and social outcasts, Baptists, Catholics, Quakers and even Jews. His theory of minority rights echoed natural law precepts in many respects and pushed beyond them in others.

That Madison was as close a student of Locke as he was

3 Drew R. McCoy, The Last of the Fathers, 137.

4 Ibid., 137, and Marvin Meyers, The Mind of the Founder, "Majority Governments," 530. 
of Montesquieu and other republican thinkers is beyond question. He was, in particular, familiar with book two of Locke's Treatises on Civil Government, where the English philosopher sketched the development of civil society. Prior to formation of civil society, Locke held, all men lived in a state of nature with complete freedom. The problem with "eden", however, lay in the fact it contained no security. ${ }^{5}$ Problems arose from each man being able to interpret and act upon the law of nature individually. Men acting as "judges in their own case" naturally had the tendency to act in their own interest. ${ }^{6}$

Locke noted that the end of civil society consisted of remedying the "inconveniences of the state of nature...by setting up a known authority to appeal to... which everyone of society ought to obey."7 The social contract, by which all participants agreed to become part of a society, was for Locke based on one important principle, the protection of property. Locke referred to this idea continually throughout the second Treatise and made clear that his definition of property extended beyond material possession.

5 Basil Wiley, The Seventeenth Century Background (New York: Doubleday, 1935), 265.

6 John Locke, Two Treatises of Government, ed. Peter Laslett, (Cambridge, Great Britain: Cambridge at the University Press, 1960), 2:2:13:293. This citation method refers to book, chapter, section, and page numbers. Two Treatises of Government hereafter cited as Treatises.

7 Ibid., $2: 7: 85: 341$. 
Civil society, he emphasized, existed to preserve the people's "lives, liberties and Estates, which I call by the general name property. " 8

Once the social contract was entered into, all who joined were to abide by the will of the majority, which was to exhibit its sovereignty through a legislative body. ${ }^{9}$ While the legislature ruled with the "preservation of society" as its fundamental purpose, the body was limited in certain respects. Locke argued that the Legislative power "cannot take from any man part of his Property without his consent."10 Since the preservation of property comprised the reason which individuals joined civil society, it seemed absurd to force them to abandon it. Such activities diminished a person's natural freedom, whereby the end of law "is not to abolish or restrain, but to preserve and enlarge freedom."11 There exists, then, in Lockean theory an essential tension. On the one hand, majority rule provided the foundation of civil society; on the other hand the authority of the majority could never be used to deprive a person or persons of their natural rights.

Madison became acquainted with the works of Locke at an early age. While attending the boarding school of Donald

8 Ibid., 2:9:123:368. Emphasis in original.

9 Ibid., 2:8:95:348-349.

10 Ibid., 2:11:138:378. Emphasis in original.

11 Ibid., $2: 6: 54: 324$. 
Robertson in the 1760 s, he had his first contact with Locke's "Essay on Human Understanding." Madison's notebook, "A Brief System of Logick (sic)," contained his lecture notes from classes at Princeton. The notebook revealed his continuing fascination with Locke's "Essay."12 Madison made his admiration for Locke clear in a comparison between Locke and Montesquieu, another man he had held in esteem. Montesquieu, Madison wrote in 1792, "was in politics not a Newton or a Locke, [both] who established immortal systems-the one in matter, the other in mind."13 Later in his life when discussing with Jefferson textbooks for law students at the University of Virginia, Madison emphasized the need for Locke's works. It was important, he held, that the doctrines of liberty, manifested in American politics, "be inculcated on those" who would sustain and administer it. "Sidney and Locke are admirably calculated to impress on young minds the rights of nations to establish their own government, and to inspire a love of free ones."14

12 Irving Brant, James Madison, 1:58-59, and JM, Editorial Notes on a "Brief System of Logick," 32-35.

13 Marvin Meyers, The Mind of the Founder, "The spirit of Governments," National Gazette, 20 February 1792, 239.

14 Ibid., Madison to Thomas Jefferson, 8 February 1825, 444. It is interesting that Madison mentions both sidney and Locke as essential to understanding the formation of government and securing of liberty. The main thrust of this thesis argues that Madison should be interpreted as sui generous, and Madison's comment above seems to be a parcel of added proof. Algernon sidney belongs to radical whig or republican ideology, while Locke stands as the heir of liberalism. Both, however, are important in Madison's eyes. 
Madison's affinity for Lockean principles manifested itself in his constant references to natural law. Commenting to Edmund Randolph about the impact of the American Revolution abroad, he stated that all of Europe would slowly "be roused to the recollection and assertion of the rights of human nature." In a 1785 letter to Lafayette, he maintained that the spanish government would fail in its attempt to permanently close the Mississippi to American navigation for "nature seems on all sides to be reasserting those rights which have so long been trampled on by bigotry and tyranny."15 In a 1793 letter, accepting an offer of French citizenship from the revolutionary government, Madison wrote that he was grateful to have played a role in "reclaiming the lost rights of mankind."16

Madison also articulated other Lockean doctrines. In Federalist 43 , he appealed to natural law and the consent of the governed as justification for the Constitutional Convention. In the third essay of his Helvidius series, he maintained the efficacy of revolution, peaceful or by bloodshed. "Every nation," he argued, "has the right to abolish an old government and establish a new one."17 One can also find Madison lecturing on aspects of the social

15 JM, Madison to Lafayette, 20 March 1785, 8:251.

16 Ibid., Madison to French Minister of the Interior, April 1793, 15:4.

17 Ibid., Helvidius 3, 7 September 1793, 15:98. 
contract in Continental Congress debates over Kentucky statehood and in the Constitutional Convention during discussion of the New Jersey Plan. ${ }^{18}$

Yet an exchange of letters with Jefferson over the former's doctrine of "the earth belongs to the living" best showed how closely Madison had read Locke. In this instance he displayed his knowledge of the Second Treatise to be greater than that of his radical friend. Jefferson argued that no generation should be bound by the debts or laws of preceding generations. Natural law presupposed that all have a part in forming the society in which they live. All must give their express consent. Madison refuted one part of his friend's idea, arguing that current generations are bound to the past by the improvements or sacrifices their predecessors had made. Madison, moreover, saw Jefferson's scheme as very impractical, a vessel of chaos. ${ }^{19}$ In a philosophic manner, he deflated Jefferson's appeal to natural law by arguing that people agree to a government and Constitution by giving a tacit assent to the country's laws and political structure. ${ }^{20}$ "Tacit assent... is to be

18 See Ibid., Constitutional Convention Speech, 19 June 1787, 10:55, Congressional Speech, 27 August 1782, 5:83

19 For a full treatment of this debate see JM, Jefferson to Madison, 6 September 1789, 12:382-388, Madison to Jefferson, 4 February 1790, 13:18-26. See also chapter four of Adrienne Koch's, Jefferson and Madison.

20 Adrienne Koch, Jefferson and Madison, 72. 
inferred from the omission of express revocation." ${ }^{21}$ In this regard Madison echoed Locke, for the English philosopher had anticipated that someone might take his theory of natural law to argue that the laws and government of civil society could not bind those who, for a variety of reasons, were not present during the formation of the social contract. The Second Treatise states:

The difficulty is, what ought to be look'd upon as a tacit consent, and how far it binds, i.e. how far anyone shall be looked on to have consented, and thereby submitted to any government, where he has made no Expressions of it at all. And to this I say, that every Man, that hath any possession, or enjoyment, of any part of the dominions of any Government, doth thereby gives his tacit consent, and is as far forth obliged to obedience of the laws of that government. ${ }^{22}$

Locke, like Madison, held to a theory of tacit consent, which prudently imparted to society a measure of social stability.

It seems clear that Madison knew Locke's works intimately. One scholar has noted that with some reservations, "Locke was indeed the prime source" of Madison's principles. ${ }^{23}$ However, critics of Madison such as Charles Beard, James McGregor Burns, Robert Dahl and John Patrick Diggins, have thought differently. They point to

21 Marvin Meyers, The Mind of the Founder, Madison to Jefferson, 4 February 1790, 232 .

22 John Locke, Two Treatises, 2:8:119:355-356. Emphasis is in original.

${ }^{23}$ Marvin Meyers, Mind of the Founder, $x x v$. 
Madison's constitutional structure of elaborate checks and balances, "auxiliary precautions," and the extended republic argument as evidence of his desire to thwart majority rule. Viewing Madison through contemporary eyes, Beardian pluralists have described Madisonian politics as a system in which political authority is divorced from economic power, and where majorities cannot directly exert their will. Much of this criticism is valid, viewed in today's context, but by the same token this line of reasoning fails to assess accurately what Madison had in mind. These critics portray Madison as concerned, above all, with protecting property, in particular the privileged economic status of the upper class. Diggins argues that "Madison feared a 'common motive,' the same 'passion' and 'interest' (the right of property) taking hold of a dominant faction as desirous of possessing property as the minority is of preserving it." 24 To prevent occurrence of such an event, and to also protect the property of the elite, "the liberty of the majority" must be frustrated so its will was not expressed directly. ${ }^{25}$

It is doubtless that Madison was a staunch supporter of property. As Edward McNall Burns has noted, property was

24 John Patrick Diggins, "Power and Authority in American Politics," American Historical Review, 86.4 (October 1981), 701-730, 710 .

25 Ibid., 710. 
almost an obsession with him. ${ }^{26}$ Federalist 10 remains a poignant reminder of Madison's adherence to property protection. Protection of the diverse faculties of man from which the rights of property originate, he insisted, "is the first object of government." 27 In Federalist 54, Madison reminded his readers that "government is instituted no less for protection of property than of the person of individuals." 28 In the Constitutional Convention, he warned of a "leveling spirit" which might lead to agrarian laws infringing on the rights of property. ${ }^{29}$ He also fought stay laws and legislation that "impugned the sanctity of contracts," both of which aided the wealthy. ${ }^{30}$

According to Diggins, the text of The Federalist

26 Edward McNall Burns, James Madison: Philosopher of the Constitution (New York: Octagon Books, 1968), 70.

27 The Federalist Papers, 10:78.

${ }^{28}$ Ibid., $54: 339$.

29 James Madison, Notes, Constitutional Convention Speech, 26 June 1787, 194.

30 Drew McCoy, The Last of the Fathers, 41 . Irving Brant has argued that Madison's support for such matters did not come from personal motives; rather his personal economic situation might have benefitted from inflationary policies. See Irving Brant, James Madison, 2:363. Edward McNall Burns also refutes the idea that Madison's object in fighting such laws was his own gain. He wanted measures enacted which banished unwholesome activity and create an atmosphere favorable for men of "industry and prudence." Rather than give carte blanche security to the wealthy, Madison wanted to impart to each farmer, merchant or small manufacturer, the rewards of their own thrift and labor. Madison also felt such measures contributed to disunionist tendencies. See Burns, James Madison: Philosopher of the Constitution, 45 
advocated an idea of property contrary to the revolutionary tradition. Ideas about property revealed in the Declaration, Diggins insists, are replaced in the Constitution with new theories. Diggins explains this shift in terms of an embrace of (David) Humean concepts, in particular his stress upon a person's right to use government to exclude others from obtaining wealth. This view of property, Diggins argues, replaced Locke's theory which stressed every person's right to property. In Diggins view, the Constitution abolished the broad definition of property that incorporated life and liberty, as well as estates. In its stead, he asserts the authors of The Federalist reduced property to economic pursuits. ${ }^{31}$ In the specific case of Madison, Diggins argues that he rested property not on a specific value of labor whereby man "wrests" things out of their natural condition which imparts value into the object, but on vague "faculties" of acquiring it, which in a Humean sense "could mean anything from skill to stealth." ${ }^{32}$

Drawing heavily on the Federalist for evidence, however, distorts Madison's view of property. While Madison was an ardent defender of the rights of property, he did not collaborate solely with the "haves" against the "have nots."

31 John Patrick Diggins, "Power and Authority in American History," 707-709.

32 Ibid., 709 . 
Furthermore, Madison did view property in the Lockean sense, despite Diggins assertions to the contrary. A study of his private and public writings over an expanded time period exposes the lopsided nature of interpretations by Diggins, Dahl and others who rely solely on the Federalist.

It was James Madison in the early 1780 s who stubbornly fought during the western land controversy to eliminate the claims of land speculating companies to tracts of 1 and beyond the Appalachians. Although the ownership of such companies rested mainly in elite hands, Madison fought their claims because a magnificent gem--the public domain--would pass "from the public to a few land mongers." ${ }^{33}$ The idea of gaining wealth other than through labor appalled Madison. A view of his political economy, influenced by both republican and liberal ideas, contradicts the idea he approved of acquiring property by "stealth." 34 Madison looked to farmers as the bulwark of the republic. ${ }^{35}$ Similarly, his desire to discriminate between original and current holders of government bonds revealed his distaste for stockjobbers. Madison's contempt for legislators who bought stock in the First Bank of the United States further

${ }^{33} \underline{\mathrm{JM}}$, Madison to Joseph Jones, 17 October 1780, 2:137.

34 For more information on Madison's political economy, see chapter iv. Also consult Drew McCoy's Elusive Republic.

35 James Madison "Republican Distribution of Citizens," National Gazette, in Marvin Meyers', Mind of the Founder, 241 . 
revealed his lack of respect for anyone who gained wealth in such an "underhanded manner." "Of all shameful circumstances of this business," he insisted:

it is among the greatest to see the members of the Legislature who were most active in pushing this Jobb [sic], openly grasping its emoluments.... The stockjobbers will become the praetorian band of the Government-at once its tool \& its tyrant... ${ }^{36}$

In Lockean terms, Madison had no respect for those who earned money in such an unnatural manner.

Furthermore, Madison never held to a narrow economic definition of property. He equated liberty with property, and often linked the terms together. During the Revolution, he reported to Edmund Randolph the effects of the rebellion abroad. Ireland, he asserted, had reaped the benefits of American resistance. "The shackles are taken off the poor Catholicks [sic] in the articles of religious worship and the tenure of real property." ${ }^{37}$ While the Irish had gained other benefits, he focused on the natural rights attained, freedom of property and freedom of conscience. Madison also reminded Congress in 1789, as he initiated the Bill of Rights legislation, that government was instituted for the benefit of the people. Such benefits consisted of the enjoyment of life and liberty, with the right of acquiring and using property, and generally of pursuing and obtaining

${ }^{36} \mathrm{JM}$, Madison to Jefferson, 10 July 1791 and 8 August $1791,14: 43,69$.

7 Ibid., Madison to Edmund Pendleton, 23 July 1782, 
happiness and safety." ${ }^{38}$ Edward McNall Burns, by no means a defender of Madison, has admitted that "in good Lockean fashion he [Madison] coupled property with liberty as the great natural rights." ${ }^{39}$

Support for property had more than a material hold on Madison. By holding property and other rights as natural, Madison put them on a pedestal upon which he hoped to hoist freedom of conscience. Understanding the depth to which Americans were committed to natural rights, Madison knew if conscience could be considered a natural right it therefore gained the same protection as property and other fundamental rights. In this respect, Madison went beyond Locke.

The persecution of Baptists in Virginia in the $1770 \mathrm{~s}$ first revealed Madison's affinity for the rights of conscience. In 1774 he confided to Pennsylvanian William Bradford that Virginia lacked that "liberal, catholic, and equitable way of thinking," which characterized Bradford's province. ${ }^{40}$ Possessed of the right of conscience, the free Pennsylvanian people, Madison believed, had produced material as well as spiritual benefits for that state. Commerce and the arts had flourished in this society where freedom encouraged "continual exertions of genius."

38 Ibid., Congressional Speech, 8 June 1789, 12:200.

39 Edward McNall Burns, James Madison: Philosopher of the Constitution, 92 .

40 JM, Madison to William Bradford, 1 April 1774, 
"Industry and Virtue" he remarked, "have been promoted." 41 Madison had not yet explicitly linked conscience to natural rights, but he had tied the faculty which produced property-industry--with freedom of thought.

In the Virginia Constitutional Convention of 1775 , Madison was a junior member. Too shy to enter into debates, he offered only a few suggestions. In the end his contribution was but one sentence in the Virginia Declaration of Rights. With the help of Patrick Henry, Madison attempted to insert into the Virginia Declaration of Rights a provision disestablishing the Anglican Church and providing for the free exercise of religion. Henry's chameleon character caused him to withdraw his sponsorship when opposition to the amendment materialized. Madison thus had to be satisfied with changing the wording of the Declaration concerning religious freedom. In place of toleration Madison suggested "free exercise" of religion. This change of phraseology, in Madison's mind, "declared freedom of conscience to be a natural and absolute right." ${ }^{42}$ This appears to be the first tangible example of Madison's thought linking natural rights and freedom of

41 Ibid., 112 .

42 James Madison, "Autobiography" William and Mary Quarterly, 2.1 (April 1945), 191-209, 199. 
conscience. ${ }^{43}$

Madison, in this instance, demonstrated how far apart his conception of natural rights was from the majority of Virginians. Most accepted the idea of toleration, which at that time meant acceptance of some form of "Christian or Protestant State."44 But Madison went far beyond this narrow view. Indeed, on matters of conscience he was closer to the radicalism of Tom Paine, who held that "toleration is not the opposite of intolerance, but it is the counterfeit of it... The one assumes the right of withholding liberty, the other of granting." 45

Madison, then, traveled beyond Locke, whose notion of religious liberty varied little from the concept of tolerance for different sects of Christians held by the majority of Americans. ${ }^{46}$ He stretched the doctrine of natural rights to include freedom of conscience. While adhering in letter to natural rights, he also tried to transcend the limitations imposed on conscience by Locke. The 1785 establishment controversy in Virginia

43 Robert S. Alley, "The Despotism of Toleration" in Alley, ed., James Madison: On Reliqious Liberty (Buffalo: Prometheus Books, 1985), 147.

44 Ibid., 148.

45 Thomas Paine, quoted in ibid., 148.

46 For a thorough examination of Locke's concept of toleration, consult Stanford Kessler's "Locke's Influence on Jefferson's Bill for Establishing Religious Freedom," Journal of Church and State, 25.2 (1983), 231-252. 
provided an example of Madison hoisting conscience onto the sacred plateau of natural rights. The key plank of his "Memorial and Remonstrance" based freedom of conscience on natural right. ${ }^{47}$ Madison deplored establishment because it infringed on a principle, which "is in its nature an unalienable right." Referring to the state's Declaration of Rights, Madison maintained that the legislature could not infringe this right because it was beyond its authority to encroach on a "fundamental right," which, "if we recur to its origin, it is the gift of nature."48 As Rhys Isaac has noted, Madison's "Memorial and Remonstrance" is explicitly contractual. Madison held that human society was an association, "in which individuals' rights and obligations would be regulated by terms on which they entered the founding compact." ${ }^{49}$ Violation of the social compact in this matter led the reserved Madison to indicate that he would support those who disobeyed the establishment law, should it pass. ${ }^{50}$

Madison's role in passage of the Bill of Rights represented his greatest effort to enshrine the doctrine of

47 T. Daniel Schumate, ed., "Introduction," The First Amendment: The Legacy of George Mason (Fairfax, VA: George Mason University, 1987), 57.

48 James Madison, "Memorial and Remonstrance," in Marvin Meyers, The Mind of the Founder 9, 15, 16.

49 Rhys Isaac, The Transformation of Virginia (Chapel Hill: University of North Carolina Press, 1982), 292.

50 JM, Madison to James Monroe, 21 June 1785, 8:306. 
conscience alongside that of property as a "fundamental right." Although initially reserved about an addition of a bill of rights, viewing it as an attempt to fundamentally change the Constitution, Madison became the force that carried the bill to its passage. Charges followed passage of the Constitution which insinuated Madison had "ceased to be a friend to conscience," and subsequently led to his campaign promise to press for a bill of rights. ${ }^{51}$ The notes for his Congressional speech in which he introduced the Bill of Rights underlines his commitment to natural rights. ${ }^{52}$ It was the only section in the notes that received such emphasis. Reinforcement of inalienable rights was, for Madison, the Bill of Rights' central purpose. As he told Congress, the rights that needed protection were those "which seem to result from the nature of the compact." 53 Moreover, Madison's greatest disappointment with the Bill of Rights stemmed from the striking out of his own amendment which restricted states from infringing the rights of conscience, speech, press or right of jury trial. The loss of this amendment "conceived...to be the most valuable on the whole list," restricted the federal government, but not the states, from invading fundamental

$11: 404$.

51 Ibid., Madison to George Eve, 2 January 1789,

52 Ibid., Notes For Congressional Speech, 8 June 1789, $12: 194$.

53 Ibid, Congressional Speech, 8 June 1789, 12:204. 
rights. To Madison the oversight was glaring. ${ }^{54}$

In a 1792 article for the National Gazette, Madison shifted his attention from merely stating that conscience was a natural right to proving it. In "Property" he made clear his understanding of the relationship between property and conscience. The seeds of this relationship (which he had hinted at in his earlier letter to william Bradford) now came to full fruition revealing a broad definition of property very similar to Locke's. ${ }^{55}$ The right of conscience and property were intertwined. Violation of one caused desecration of the other.

"Property" is the quintessential piece of Madison's liberal philosophy. This essay, like his other works regarding conscience, was written in the natural law tradition. ${ }^{56}$ In it he defined property, "in its larger and juster meaning" as a concept which embraced "everything to which man may attach a value and have a right, and which leaves to every one else the like advantage." 57 Madison noted that man's property extended beyond tangible things. "In a word, as a man is said to have a right to his property, he may be equally said to have a property in his

54 Ibid, Congressional Speech, 17 August 1789, 12:344. 55 See note 39 for Madison's letter to Bradford.

56 Neal Riemer, James Madison: Creating the American Constitution, 120 .

57 JM, "Property" 27 March 1792, 14:266. Emphasis in original. 
rights."58 To emphasize the importance of the latter half of his maxim, Madison characterized conscience as "the most sacred property of all...the exercise of that right being a natural and unalienable right." ${ }^{59}$ Government must, therefore, protect equally conscience and property. A government that protects only the right to property, and not property in rights was not just. As Neal Riemer has argued, there is no mistake more profound than identifying Madison's view of property as strictly economic and conservative. Madison did not see government's role as guarding the wealthy against the poor. Property, both the right to and protection of, deserved security because it was a natural right. ${ }^{60}$ Conscience, likewise, deserved the same protection since it derived from the social compact. In so far as the latter has become, at least in public rhetoric, a principle equal to other natural rights in American society, it has done so largely through Madison's efforts.

Madison's belief in the protection of natural rights also led to his firm stance for minority rights. Classical republican doctrine stressed suppression of minority rights for the "sake of the public good." 61 Such a doctrine was

58 Ibid, 266.

59 Ibid., 266.

60 Neal Riemer, James Madison: Creating the American Constitution, 122 .

61 Gordon Wood, The Creation of The American Republic, 1776-1787, 62 . 
anathema to Madison. The doctrine of minority rights is sprinkled throughout his writings. Madison's fear of majority tyranny is most concisely summed up in a letter to George Washington written shortly before the Constitutional Convention. "The majority who alone have the right of decision have frequently an interest real or supposed in abusing it."62 The majority must rule, but majority rule had boundaries which it could not overstep. The cure for such a problem, according to Madison, consisted of founding a "stable government not infringing fundamental rights." 63 The Constitution, for the most part, fit Madison's description. His concern for minority rights anticipated Tocqueville's critique of a conformist American society by forty years. Yet his doctrine of minority rights is neither conservative nor aristocratic. It is simply an affirmation of Locke's thesis that civil society should never infringe fundamental rights. Contrary to pluralist opinion, Madison was not allied with upper classes in an effort to oppress the majority. Indeed, when one analyzes how Madison put his doctrine of minority rights into practice it is the upper classes he aligned against.

Madison belonged to the gentry class, but he was not in solidarity with it. At the Constitutional Convention, he 385 .

$62 \underline{\mathrm{JM}}$, Madison to George Washington, 16 April 1787, 9:

63 Ibid., Madison to Jefferson, 19 March 1787, 9:318. 
opposed property qualifications for elected officials. There he noted that "landed possessions were no certain evidence of great wealth." The unjust laws of the various states "proceeded more often from this class of men [large land owners] than any others."64 Seven years later in Congressional debates taxation, Madison called for taxes on luxuries. Referring his colleagues to the words of Thomas Paine, Madison described "a great estate" as the greatest luxury. ${ }^{65}$

Madison, furthermore, participated in struggles against his own class. As a foremost supporter of the Baptists in Virginia, he helped deal a blow to gentry dominance in that state. Although he professed no affection for Baptist "enthusiasm," he (and his father) fought for, and provided protection for them on occasion. ${ }^{66}$ As a vestryman, the senior Madison enforced church discipline. One of the vestryman's most important duties consisted of putting Baptists in jail for preaching without licenses. In this distasteful task James Madison, Sr. refused to take part. ${ }^{67}$ Rather than discouraging Baptist activities' like a good vestryman should have, he tolerated, and even allowed,

64 James Madison, Notes, 26 July 1787, 375.

65 JM, Congressional Speech, 2 May 1794, 15:321-322.

66 James Madison, "James Madison's Autobiography," William and Mary Quarterly, 198.

67 Irving Brant, James Madison, 1:52. 
Baptist meetings near his own home. Indeed, in May of 1771, four to five thousand Baptists assembled at Blue Run Church in Orange County. While this meeting was near the Madisons' estate, they made no effort to stop it, a passive but bold statement of the family's support for the Baptists. ${ }^{68}$

The younger Madison's service for the Baptists, however, went far beyond his father's. As legislator and pamphleteer Madison's opposition to Episcopal establishment initiated a fight for freedom of conscience that had broad social implications. Rhys Isaac has noted that the established church composed "an integral part of the fabric of colonial Virginia society and its system of authority."69 And the Baptist challenge to the elite was not treated lightly by Virginia gentry. Establishment had the support of the cream of Virginia's gentry, among others, George Washington, Patrick Henry, and Richard Henry Lee. Yet, Madison's Lockean principles caused him to fight his own class and defend the right of an embattled social minority. If other members of the gentry knew that the establishment controversy contained implicit social implications, Madison doubtless also knew; but he chose to join those working to break the gentry monopoly on political power. The result of this struggle saw the ascendancy of a

68 Rhys Isaac, The Transformation of Virginia, 17401790, 192, and Irving Brant James Madison, 1:70. 157.

69 Isaac, The Transformation of Virqinia, 1740-1790, 
contractual conception of authority at the expense of the old social authority of patriarchy in Virginia. The principle of individual autonomy began to change "late eighteenth-century Anglo-Virginians' perceptions of the world and the expectations they had of it."70 Madison played an important role in this transformation.

His battle for other minorities such as Catholics, Jews, and Quakers, carried itself into Congress. In 1790, Catholics in America numbered approximately thirty five thousand out of a population just under four million. ${ }^{71}$ Persecution had erupted during the Glorious Revolution and sporadically throughout the eighteenth century wars between Britain and France, as well as after passage of the Quebec Act. Virginia proved one of the worst offenders against Catholic liberties. Besides suffering disenfranchisement, Catholics were prevented from acting as guardians, or serving as witnesses. They were barred from settling in large groups, owning horses worth more than five pounds, or possessing firearms. ${ }^{72}$ Although the Revolutionary alliance with France helped ease some fears, "socially speaking, Catholics endured as a suspect minority."73 In 1790,

70 Ibid., 311

71 John Tracy Ellis, American Catholicism (Chicago: University of Chicago Press, 1956), 42 .

72 Ray Allen Billington, The Protestant Crusade, $1800-$ 1860 (New York: Rhinehart and Company, Inc., 1952), 10 .

73 Ellis, American Catholicism, 42 . 
Catholics enjoyed civil liberties in only five out of thirteen states. The eruption of anti-Catholic prejudices in the 1840 s could not have occurred without Americans being steeped in the anti-papal tradition. ${ }^{74}$

James Madison's support for Catholics, conversely, stretched back to the 1780 s when he served as a member of the Virginia House of Delegates. In an unsuccessful bid to convince the House to amend the Virginia Constitution, Madison listed as one of the document's defects the exclusion of "papists and recusants" from the franchise. ${ }^{75}$ Later in 1794, when Representative Samuel Dexter of Massachusetts ridiculed the idea that Roman Catholics could become attached to republican principles, Madison defended them. Catholicism was not inherently anti-republican, Madison countered. Pointing to the democratic character of the Swiss Cantons, many of which were Catholic, he argued there was nothing inconsistent with their religion and the "purest republicanism." Many Catholics had proven themselves in the recent struggle with England, and thus, he pointed out, deserved the title of "good citizen."76

Madison also championed the rights of Quakers and Jews. He believed firmly in the rights of conscientious objectors. $8: 78$.

74 Billington, The Protestant Crusade, 1.

75 JM, Notes on Virginia Constitution, 14 June 1784, 76 Ibid., Congressional Speech, 1 January 1795, 15:432433. 
In introducing the Bill of Rights, Madison had attached to the amendment concerning the right to bear firearms a clause which stated no person religiously opposed to bearing arms "shall be compelled to render military service in person."77 Having failed in this instance, Madison tried again, in Congressional debates over the militia, to secure an exemption for Quakers. He proposed that all persons who claimed exemption from military duty because of religious beliefs should present a certificate indicating their church membership. Instead of service, Madison proposed that each would pay a sum of money, although his personal preference was that the "exemption should be made gratuitous."78 Madison's bill again failed to become law, but it provides another example of his commitment to minority rights.

In 1790 population estimates of Jewish Americans numbered between 1500 and 2000. Although American Jews fared better than their counterparts in Europe, even Rhode Island, the most liberal of all the colonies, treated them as strangers, refusing them the right to naturalization. ${ }^{79}$ At the time the Constitution was passed, only Virginia, Pennsylvania, Delaware, South Carolina, and Georgia had

77 James Madison, Congressional Speech, 8 June 1789, in Marvin Meyers, The Mind of the Founder, 216.

78 JM, Congressional Speech, 23 December 1790, 13:330.

79 Morton Borden, Jews, Turks, and Infidels (Chapel Hill: University of North Carolina Press, 1984), 24. In 1761, Rhode Island officials denied two Jews applications for naturalization. 
repealed onerous civil restrictions on Jews. Ironically, it took Maryland, founded as a haven for those religiously persecuted, twenty seven years of continual referendums on the "Jew law" to pass it. ${ }^{80}$ Federalist attacks on Jeffersonians between 1795 and 1800 appealed at times to anti-semitic prejudices. ${ }^{81}$ Jews, like Catholics, were victims of deep seated suspicions.

But despite wide spread anti-semitism, American Jews found a friend in James Madison. He wrote occasionally to Jews "expressing his respect for their fortitude and patriotic attachment to the United States." ${ }^{82}$ As a member of the Continental Congress Madison at times received financial aid from Haym Solomon, who refused "obstinately" all repayment. ${ }^{83}$ In 1818 , Mordecai M. Noah wrote to Madison thanking him for his service to the Jews, in particular his fight for religious freedom. Madison's support, Noah testified, was an important reason that he and other members of his faith had reaped many blessings since

Ibid., 37-40.

81 See Morris U. Schappes, "Anti-Semitism and Reaction, 1795-1800" in Abraham Karp, ed., The Jewish Experience in America 3 vols. (New York: Ktav Publishing House, 1969), 1: 362-390, for a sampling of Federalist propaganda attacks containing anti-Jewish messages.

82 Robert Ketchum, "James Madison's Religion," in Robert Alley, ed., James Madison: On Religious Liberty, 185. I: xxii.

83 Abraham Karp, ed., The Jewish Experience in America, 
coming to America. ${ }^{84}$ with the notable exception of Indians and blacks, Madison had a deep concern for minorities existing on the margins of the American society, and this concern was an important aspect of his liberal ideology. Majority rule must always respect the fundamental rights of all, including socially ostracized groups. Madison fought for equal rights on behalf of several minorities, opposing at times his own class. All must have an equal right to property, as well as a property in rights. Madison's opposition to majority rule was hardly undemocratic. His doctrine of minority rights posited that a system of popular government that failed to protect natural rights was tyranny clothed in a different manner. While the theory that popular majorities can abuse power has gained acceptance as a maxim of American political thought, Madison has received little credit for it. Madison fought tyranny wherever he found it. He feared tyranny of any kind, whether by the few or the many. "As Madison never tired of insisting, the rich could oppress the poor, the poor could injure the rich, merchants could harm the farmers, and farmers could damage merchants." 85 He championed the individual and his rights to economic, political, religious, and intellectual freedom. The

84 Ibid., 359.

${ }^{85}$ Neal Riemer, James Madison: Creating the American Constitution, 122 . 
Constitution, hardly a perfect document to Madison's mind, attempted to reconcile this tension within Locke's doctrine between majority rule and individual rights. Madison understood that ill use of power, either personal or political, "could cut many ways." 86 He wanted a system of government strong enough to govern effectively, but not so powerful that it could jeopardize the natural rights of individuals. In this regard, it may be that Madison was too Lockean. He believed majority rule could exist with adequate protection for minorities of all classes and beliefs. Madison held that a system of popular government drawing solely on the sovereignty of a heterogenous people, combined with a diffused balance of power among the various governmental branches, could govern effectively and secure fundamental rights. ${ }^{87}$ Critics may object to Madison's methods--that is, his means of securing majority rule with safety for minorities--but not his end. If Madison's theories for joining majority rule with minority rights has proven archaic in today's world, his goal remains valid. Any system of rule that stifles or fails to protect individual development deserves no one's approbation. Scholars have overlooked the democratic character of

86 Ibid., 122.

87 For a fairly recent interpretation that argues for The Federalist's concern for republican government and popular sovereignty, consult David F. Epstein, The Political Authority of the Federalist (Chicago: University of Chicago Press, 1984). 
Madison's theory of minority rights. Instead of looking at his theory in action, they mistakenly derive his doctrine from class status. This same type of narrow interpretation has hampered understanding of another aspect of Madison's liberal ideology, that which follows from his analyses of "faction" and "interest".

Madison's theory of interest and faction, as he developed it in The Federalist, has received considerable attention from scholars. It has been viewed in basically two different manners. The republican view, that of Gary Wills and Gordon Wood, maintains that The Federalist's emphasis on the multiplicity and interplay of interests allows for the negation of interests to the end of promoting the public good. ${ }^{88}$ In contrast, pluralists such as Laski, Bentley, Lippman and others, while acknowledging Madison's dark view of interest and faction, contend that the structure of government and politics he espoused was essentially modern. ${ }^{89}$ Publius-Madison, they held, recognized the interest-oriented nature of man and championed a republican system in which government provided the arena for competing interests to vie for ascendancy. Thus one school sees Madison conceiving government's role as

${ }^{88}$ The best example is Garry Wills' Explaining American: The Federalist.

89 See Paul F. Bourke's, "The Pluralist Reading of James Madison's Tenth Federalist," for a concise analysis of this interpretation. 
blocking interests, while the other depicts it as recognizing faction and providing the framework for interest competition. Both describe Madison as viewing interest in a negative manner.

As such both views reveal the danger of interpreting Madison solely through The Federalist. The same Madison who argued pessimistically in the Federalist 10 that the power of self-interest was so strong "it is in vain to say that enlightened statesmen will be able to adjust these clashing interests" was the same man who stated before the House that "the great principle of interest is a leading one with me."90 One remark painted interest as negative force, the other celebrated it. Evidence exists that casts a cloud over the image of interest portrayed in The Federalist. Indeed, as legislator, Madison showed that investigating and promoting the interests of one's constituents was important to him.

The need to know the interests of a legislator's constituents prompted Madison, during Congressional debates in 1783 over a commercial treaty with Great Britain, to request "that the commercial interests of Virginia [be] thoroughly investigated \& the final sense of the state expressed to its representatives."91 Madison saw nothing

90 The Federalist, 10:80; JM, Congressional Speech, 21 April 1789, 12:99.

91 Ibid., Madison to Edmund Randolph, 20 May 1783, 
wrong with verifying Virginia's interests in the matter and then articulating them to Congress. In fact, as a member of the Continental Congress, the protection of Virginia's interests in the navigation of the Mississippi and the western land controversies displayed Madison's firm commitment to his state's "distinctive interests." 92 The French Minister, Chevalier de La Luzerne, noted that despite Madison's devotion to France, his honest character, and desire "to do good works,...he is not free from prejudices in favor of the various claims of Virginia." ${ }^{93}$ Similarly, in 1791 Madison refused to present an anti-slavery Quaker petition to Congress, because such a request would cause him to violate the interests of his constituents, from whom "I derive my public station." Replying to Quaker John Pleasant, Madison refused to make "use of my situation...to become a volunteer in giving a public wound, as they [his constituents] would deem it, to an interest on which they set so great value."94 Madison even promoted slavery, an

92 Lance Banning, "James Madison and the Nationalists," William and Mary Quarterly 40.2 (April 1983), 228. The first part of Banning's article provides a concise account of Madison's involvement in the dispute over western land claims, as well as the fight to secure free navigation of the Mississippi.

93 Quoted in Irving Brant, James Madison, 2:14.

94 Ibid., Madison to Robert Pleasants, 30 October 1791, 14:91. Madison also refused to present the petition on the grounds it would do more harm than good. Analyzing the present climate of opinion, Madison thought reaction to Quaker petitions might lead to restrictions on the rights presently enjoyed which allowed an individual to free their 
institution he ethically despised but did little about, to preserve the interests of Virginia citizens.

If representatives were to promote interests, government, moreover, was bound to protect interests and to insure al1 segments of society were represented. In 1785 , Madison criticized the Articles of Confederation for its failure to protect interests. "The suffering part, even a minor part, can not long respect a government which is too feeble to protect their interests."95 During the Constitutional Convention, Madison declared that "it was politic as well as just that the interests and rights of every class should be duly represented and understood in public councils." 96

As these passages indicate, it is clear that Madison believed interest must have a voice in government. To guarantee that American's republican government understood and represented the interests of a heterogenous society, Madison advocated a detailed census. When the census bill was introduced in January of 1790, Madison confided to Jefferson that it provided "a kind of information extremely

own slaves. His prediction proved true. The continued din for manumission led to an 1806 act by the Virginia legislature which required that free slaves "leave the commonwealth within twelve months." JM, Editorial Note, $14: 92$.

95 Ibid., Madison to Monroe, 7 August 1785, 8:334.

96 Ibid., Constitutional Convention Speech, $26 \mathrm{July}$ $1787,10: 117$. 
requisite to the legislator, and much wanted for the science of political economy." 97 An enlightened Madison proposed, therefore, a schedule that distinguished between gender, age, and race, as well as one that specified "the number of persons employed in different professions and arts...such as merchants, mechanics, manufacturers, etc., etc." 98 To Madison such detail was vital. "Descriptions of the several classes into which the community was divided, he insisted, should be accurately known."99 Armed with such information, legislators could then "make proper provision for the agricultural, commercial and manufacturing interests."100 Furthermore, as the country grew, he asserted a thorough census would allow legislators "an opportunity of marking the progress of the society, and distinguishing the growth of every interest."101 Against critics of the proposed census, Madison gave no ground:

In order to accommodate our laws to the real situations of our constituents, we ought to be acquainted with that situation. It may be impossible to ascertain it as far as I wish, but we may ascertain it so far as to be extremely useful when we come to pass laws affecting $13: 41$.

${ }^{97}$ Ibid., Madison to Jefferson, 14 February 1790,

98 Ibid., Congressional Speech, 26 January 1790, 13:9.

99 Ibid., Congressional Speech, 25 January 1790, 13:89 .

100 Ibid., Congressional Speech, 26 January 1790, 13:9.

101 Ibid., Congressional Speech, 25 January 1790, 13:8- 
particular descriptions of people. ${ }^{102}$

To bolster his case further, he pointed to recent bills passed by the House concerning the manufacturing, agriculture and commercial sectors of society. If Congress had the benefit of census information, he held, his fellow representatives could have based their arguments on facts, not conjecture. ${ }^{103}$

Evidence such as this leads one to question the interpretation of Madison devising the Constitution to thwart interest. If anything, he did his best to insure that various interests made their way to the national government. Yet by the same token a modern, pluralistic interpretation of Madison as interest broker does not accurately describe the views he expressed outside of The Federalist. The world of modern politics was alien to Madison, and thus he did not hold that the public good

102 Ibid., Congressional Speech, 2 February 1790, 13:1516. Madison also incorporated a suggestion from

Massachusetts Representative, Theodore Sedgwick, into the census bill. Sedgwick wanted to include a schedule that included identification of the professional trades, clergy, physicians and lawyers. Madison replied he had no objections to including the learned trades, but was wary of including clergy since "the general government is proscribed from interfering, in any manner whatsoever, in matters of religion." Madison's detailed schedule was, to his disgust, thrown out by the Senate. JM, Madison to Jefferson, 14 February 1790, 13:41.

103 JM, Congressional Speech, 2 February 1790, 13:16. 
resulted from the natural competition between interests. ${ }^{104}$ His liberal orientation was, at every turn, tempered by his republican ideal of the "public good," and informed by the eighteenth century concern that man's tendency to self interest, when pushed to extremes, perverted the natural order.

One thus finds in Madison's discourse a curious, and at first glance contradictory, blending of interest and the public good. In 1782, Madison complained that a lack of knowledge about state interests hampered Congressional action on currency problems. The lack of information "in all questions relative to this subject, makes it difficult for us to deduce the general interest from a just and fair comparison of particular interests."105 Here and elsewhere, Madison linked the public good, "the general interests," to an adequate knowledge of "particular interests." For example, at the Virginia ratifying convention, he supported election of the president by the electoral college because it satisfied the conflicting interests of the large and small states and in doing so, he

104 Gordon S. Wood, "Interest and Disinterestedness in the Making of the Constitution," in Richard Beeman \& et. al., eds. Beyond Confederation: Origins of the Constitution and American National Identity (Chapel Hill: University of North Carolina Press, 1987), 96.

105 JM, Madison to Edmund Randolph, 3 December 1782, 
reasoned, accomplished the public good. ${ }^{106}$

Concern for the general interest also induced Madison in 1794 to reject the interests of merchants in discussion over commercial discrimination. He did not object to their interests being voiced, but he maligned the attitude of Congressmen who treated merchants' opinion in matters of trade as "oracles." Such conduct seemed unthinkable to Madison, since representatives of the House were bound to watch over the "joint concerns of the whole."107

Madison's definition of interest thus does not fit neatly within the pluralistic paradigm. He confided to James Monroe in 1786 that no maxim appeared more misapplied than "the current one that the interest of the majority is the political standard of right and wrong." If one took the word " 'interest' as synonymous with 'ultimate happiness' in which sense it is qualified with every necessary moral ingredient," he granted that the idea was true. However, by taking interest in the popular sense, "as referring to immediate augmentation of property and wealth, nothing can be more false."108 Interest, to be effective and just, must align with the needs of the whole. A balance between self-interest and the public good must be struck.

106 Ibid., Speech at the Virginia Ratification Convention, 11:154.

107 JM, Congressional Speech, 31 January 1794, 15:236.

108 Ibid., Madison to Monroe, 5 October 1786, 9:141. 
In the last example, one finds traces of PubliusMadison. Interest taken to its extreme led to tyranny. When interest super-seceded reason, it took on its evil nature, faction. ${ }^{109}$

Madison surmised that interest, within its proper sphere, deserved the full attention of government. Guided by reason, and a knowledge of interests, not only of one's constituencies but of the entire nation, elected officials could "deduce the general interest from a just and fair comparison of particular interests." ${ }^{110}$ With such knowledge, as the basis of reflection and debate, Madison believed that legislators could reach a consensus on just what constituted the "public good." Obviously, this mode of interest expression was politically deferential. Madison advocated investigation and vocalization of interests, but did not guarantee that government would recognize the validity of any specific interest. Government's role consisted of merging interest and the public good onto a middle ground whereby the antithetical nature of the two disappeared.

How does one reconcile the Madison who denounced "faction" in The Federalist with the Madison who maintained

109 Daniel Howe, "The Political Psychology of the Federalist," 485-509.

110 James Madison, "Republican Distribution of Citizens," National Gazette, in Marvin Meyers, Mind of the Founder, 241 . 
that the public good could not be discerned without intimate knowledge of the interests of the nation? Perhaps resolution of the dilemma centers on seeing The Federalist as Madison's portrayal of government functioning at its worst, that is when interest has usurped reason in the minds of elected officials. Publius-Madison stressed the reliability of a system which had its own built in check against self aggrandizement. One finds Madison, in the midst of party strife five years after passage of the Constitution, reiterating his assertion that the best provision for a stable government rested with "an equilibrium in the interests and passions of the society itself..."111 Yet Madison's statements only admit that diversity of interests provided security for republican government. He does not admit that it is the best way to govern. It is now known that The Federalist was aimed at the elite, educated parts of society. ${ }^{112}$ Publius' goal was to convince members of the upper class that their status and property could still remain secure under the constitution, even if "enlightened" (upper class) leaders were not at the helm. Obviously, the essays had a more partisan character than is currently acknowledged.

111 JM, Notes for National Gazette Essays, 19 December 1791--3 March 1792, 14:158-59.

112 See Daniel Howe's, "The Political Psychology of the Federalist," 485-509; and Albert Furtwangler's, The Authority of Publius: A Reading of the Federalist Papers (Ithaca, N.Y.: Cornell University Press, 1984.) 
As Garry Wills has pointed out, development of a political system that treats every man as a knave does not necessarily imply that only selfish goals exist. Rather such a strategic presumption allowed Madison to talk of safeguards without precluding virtue. ${ }^{113}$ Madison's theory of interest reflected his ideas about human nature, most succinctly expressed in Federalist 55:

As there is a degree of depravity in mankind which requires a certain degree of circumspection and distrust, so there are other qualities in human nature which justify a certain portion of esteem and confidence. ${ }^{114}$

If The Federalist dwelled on the negative aspects of interest, Madison enunciated in other writings the positive side. In these latter instances he portrayed a symbiotic relationship between interest and the common good. Interest must always be tied to the public good, but cognizance of the public good rested on an intrinsic knowledge of interest.

113 Gary Wills, Explaining America: The Federalist, 192.

114 The Eederalist Papers, 55:346. 
THE SUI GENERIS MADISON: A PRUDENT POLITICAL ECONOMY

In his theory of interest Madison fused strands of republican and liberal ideas, indicating that he did not find the two paradigms incompatible. Not surprisingly, historians have started to see things from a Madisonian viewpoint. Recently, historians have approached an uneasy consensus between liberal and classical interpretations of the founding period. Both sides have backed away from earlier assertions that one or the other ideology dominated the American revolutionary and founding era. Lance Banning, for example, has admitted that he and other historians of classical republicanism have over-emphasized the importance of these doctrines and slighted the presence of Lockean ideas. ${ }^{1}$ Many scholars now agree that a variety of political languages were present during this time. Isaac Kramnick has identified four ideologies which contributed to a "profusion and confusion of political tongues among the founders."2 The correct view is that there was no homogenous political

1 Lance Banning, "Jefferson Ideology Revisited: Liberal \& Classical Ideas in the New American Republic," William and Mary Quarterly, 43.1 (January 1986): 3-19, 12-15.

2 Isaac Kramnick, " 'The Great National Discussion': The Discourse of Politics in 1787," 4 . 
language at the time, and that to educated men use of one ideology seemed compatible with the use of others. ${ }^{3}$

The previous chapters have examined the ways in which Madison's thought coincided with classical and liberal creeds. Yet if both ideologies existed in his mind, it follows that they were interwoven. This is evident in his views on political economy, which display his molding and merging of different political languages into one. In the end, this is to say, Madison's writings blended classical with liberal ideas, to the end of promoting a society which freed the individual to fulfill his economic potential, and yet consulted the public good. As Madison himself testified, "the citizens of the U.S. know that their individual interest is connected with the public [interest]." 4

From the early 1780 s through 1795 Madison worked to remove the shackles from an American economy dependent on British credit, merchants, and ships; instead, as a legislator he promoted a society compatible to the American "genius." A study of Madison's thought on political economy during this time shows him synthesizing strands of different theories. He incorporated those ideas into an ideology conditioned to the realities of American society.

3 Ibid., 4.

${ }^{4}$ JM, Congressional Speech, 9 May 1789, 12:146. 
Before looking at Madison's legislative attempts to secure the American republic, it is instructive to outline his view of the ideal society. His support for free trade was one of the most consistent themes of his ideology. In a 1785 letter to James Monroe, for example, Madison confided to his friend that "a perfect freedom is the system which would be my choice." During a Congressional speech four years later he similarly proclaimed that "commerce ought to be as free as the policy of nations will admit." In the same vein, throughout the meetings of the third congress Madison repeatedly called himself a friend of free trade and voiced support for a doctrine "which gives industry a free course under the impulse of individual interest and the guidance of individual sagacity." 5

According to Madison, not only did free trade allow individuals to pursue their economic goals, it encouraged peaceable relations between nations. This communication unified trading partners and made them dependent on the other's goods. When such a relationship prevailed, he held, countries hesitated to declare war on one another, for peace served and promoted a nation's commerce. Free trade not only liberated the individual but restrained international

5 Ibid., Madison to Monroe, 7 Aug. 1785, 8:333; Ibid., Congressional Speech, 8 April 1789, 12:65. 
violence, the greatest danger to republican government. ${ }^{6}$

According to Madison, however, free trade alone did not in itself sustain republican principles. Commerce must carry the goods that resulted from the most exalted of occupations, agriculture. To his mind, a robust commerce carrying American agricultural produce overseas provided a crucial safety valve for republicanism. Agriculture, then, provided the foundation for Madison's concept of political economy. Agriculture, in his estimation, needed encouragement because it constituted "the great staple of America." In this regard he agreed with Tench Coxe's statement that agriculture was "the spring of our commerce and the parent of our manufactures." 7

This defense of agriculture as the true basis of prosperity aligned Madison with the concepts of Adam Smith and the French physiocrats. Madison and Smith stood for the producer of natural goods, foodstuffs. In the Wealth of

6 Ibid, Notes for a Congressional speech, 9 April 1789, 12:68, and Ralph Lerner, "Commerce and Character: The AngloAmerican as New Model Man," William and Mary Quarterly, 36. no.1 (January, 1979): 14-15. Lerner provides a concise account of this contemporary idea that commerce would induce more pacific relations between nations. He points out that Hamilton was the "outstanding demurrer" to this concept. Hamilton believed free trade ideas nonsense because they lacked an understanding of the true nature of commercial relations between nations.

7 Ibid, Congressional Speech, 9 April 1789, 12:71, and Tench Coxe, "An Enquiry into the Principles on which a Commercial System for the United States should be Founded," (June 1787), quoted in Cathy Mason and Peter Onufs" "Toward A Republican Empire: Interest and Ideology in Revolutionary America," American Quarterly, 37.4 (1985):496-531, 524. 
Nations, Smith asserted that the rapid progress of Americans resulted from their ability to concentrate their capital in agriculture. ${ }^{8}$ French physiocrats held that agriculture was more natural and valuable to a nation than an obsession with manufacturing luxuries. ${ }^{9}$

It is important to point out that the type of agriculture Madison advocated was not limited to subsistence farming. The whole purpose of free trade was to take advantage of the fact that Americans produced far more than they needed. This surplus would be shipped to countries needing essential staples. In the last part of the eighteenth century, the growth of markets in Europe and the West Indies prompted American farmers to pursue a mixed husbandry, in particular wheat production. ${ }^{10}$ while

${ }^{8}$ C.R. Fay, "Adam Smith, America, and the Doctrinal Defeat of the Mercantile System," Quarterly Journal of Economics, $48(1933-34)$ : 304-316, 313-314.

9 Drew R. McCoy, The Elusive Republic, 52.

10 Joyce Appleby, "Commercial Farming and the 'Agrarian Myth' in the Early Republic," Journal of American History, 68.4 (March 1982): 839-840. The importance of the wheat market had a personal effect on Madison. In a letter to Thomas Jefferson in June of 1793, Madison asked for his friend's comments on a system of crop rotation he had formed. The number of acres of wheat planted each year, according to Madison's system, was double that of any other crop. JM, Madison to Jefferson, 29 June 1793, 15:40-41. Joyce Appleby points out in, Capitalism and a New Social Order: The Republican Vision of the 1790s, 43, the city of Baltimore arose in the $1790 \mathrm{~s}$ from the grain trade. Two centers of raising and marketing agriculture produce, Philadelphia and New York, grew at a rate almost double that of the rest of the nation. This work of Appleby's and the other cited above have gone a long ways towards correcting the assumption that because the Jeffersonians championed 
classical republicans feared this kind of prosperity because it led to accumulations of wealth and luxury, and thereby accelerated the decline of the body politic, Madison saw surplus crops as a positive measure of the individual industry of the American people. The demonstrated productive capabilities of American farmers, in turn, reinforced Madison's belief that industry and labor, in most circumstances, should be left alone. Not even the wisest legislature could create, through legislation, a more favorable atmosphere for labor than nature. ${ }^{11}$

While Madison rejected a classical view of subsistence agriculture production he still retained classical ideas about the relationship between independence and property ownership. In classical ideology the vitality of republican government rested on a foundation of independent landowners. Each was capable of providing for their own needs, and each zealously guarded the political liberty produced by their economic independence. When an individual became dependent

agriculture they adhered to a backward looking ideology while the Hamiltonians are viewed as advocates of modernity. This is assumption that McCoy's Elusive Republic builds on in characterizing the Jeffersonians as followers of classical republican ideals. As Appleby correctly points out in the "Agrarian Myth," the battle between the Jeffersonians and the Federalists should be seen as a struggle between two different ideas of capitalistic development. Historians, like McCoy, living in an industrial age see the Jeffersonian's enthusiasm for agriculture as an attachment to the past and those who advocated a manufacturingfinancial political economy as progressive.

11 JM, Congressional Speech, 9 April 1789, 12:71. 
on another for subsistence, that person also lost his political liberty. The larger the number of people who lacked independence, the greater the likelihood of corruption. In this regard Madison aligned himself with classical theories.

Madison believed that republican government needed to rest on a foundation of independent people who supplied their own needs. Like other classical republicans, he felt that when people were independent they jealously guarded their liberty and republican government. Thus, in the Constitutional Convention of 1787, he remarked that the freeholders of the United States provided the "safest depositories of Republican liberty."12 Occupations to be avoided "consisted of those that make one class of citizens dependent on another."13 Madison reiterated the political and economic importance of an independent citizenry in a March 5, 1792, article for the National Gazette entitled "The Republican Distribution of Citizens." "The class of citizens who provide at once their own food and their own raiment," he held, "may be viewed as the most truly independent and happy. They are more; they are the best basis of public liberty and the strongest bulwark of public

12 James Madison, Notes, 403.

13 JM, "Fashion," National Gazette, 20 March 1792, $14: 20$. 
safety."14 For Madison, the freedom and happiness of American society increased in proportion to the agricultural segment of the population.

In a different vein, however, Madison looked at the role property played in securing republican government in a way that diverged markedly from the classical concept. The classical conception of property viewed land not as a means of making money, but rather as a way of "anchoring the individual in the structure of power and virtue, and liberating him to practice these ideas."15 Possession of ample land allowed certain citizens enough wealth to spend the majority of their time engaged in securing the common good through politics. On the other hand, when Madison referred to freeholders as the most secure source of political liberty, he alluded not to owners of vast estates who lived off the proceeds of their land; rather Madison celebrated the families who worked their land and who reaped the benefits of their own labor. In contrast to British laborers toiling in degrading, dependent employment in manufacturing, Madison gloried in "the independent situation and manly sentiments of American citizens, who live on their own soil," and "whose labor is necessary for its

14 Marvin Meyers, ed. The Mind of the Founder, 242-243.

15 Joyce Appleby, Capitalism and a New Social Order, 9. 
cultivation..."16 American society would continue to grow as individuals labored on their property to produce surplus natural goods. Virtuous conduct and industry, therefore, naturally emanated from a Republican government which allowed citizens the freedom necessary to develop their faculties.

Yet, if the American economy was to be based on aggressive exporting of agricultural goods, there needed to be the means available to transport the goods in ship bottoms other than foreign ones. Madison advocated the creation of a large merchant fleet to streamline the flow of American foodstuffs overseas. In a speech to Congress in May of 1789, he declared himself a friend of shipping. "I....shall be always ready to go to as great [of] lengths in favor of that interest as any gentleman on the floor."17 A month earlier, Madison had attacked a proposal to place a heavy duty on hemp because such a measure threatened the shipbuilding industry. ${ }^{18}$ Besides securing independence for American goods transported overseas, the presence of a sizeable fleet provided protection for American coasts in time of war, and also promoted industry. Because America

16 JM, "Fashion," National Gazette, 20 March 1792, 14:258. Emphasis in the quote is mine.

17 Ibid., Congressional Speech, 4 May 1789, 12:120. Madison's enthusiastic support for an expanded American merchant fleet should dispel any lingering visions of Madison as a supporter of yeoman agriculture.

18 Ibid, Congressional Speech, 16 April 1789, 12:84. 
shipped bulky products, which required more room in ship holds than manufactured goods, Madison reasoned that as Americans produced more goods for export their shipping capacity must also grow. ${ }^{19}$ Economic opportunities would abound for those who ventured to build ships and carry American goods, and Madison meant to encourage such ventures.

Manufacturers also appeared prominent in Madison's ideal society, but in a secondary role to agriculture. For him, manufactured goods should not become the object of export trade, but rather provide a source of essentials for farmers. Madison remarked that the United States was fortunate because "so much of the ordinary and most essential consumption takes place in fabrics which can be prepared in every family, and which constitute, indeed, the natural ally of Agriculture. The former is work within the doors, as the latter is without." ${ }^{20}$ The utility of manufacturers was based not only on their ability to supply necessities, but also to the degree they helped promote republican society. Manufacturing occupations which were "least favorable to vigor of body, to the faculties of the mind, or to the virtues or to the utilities of life,...ought to be seen with regret, as long as occupations more friendly

19 Ibid., 3 Jan. 1794, 15:169-170.

20 Marvin Meyers, The Mind of the Founder, "Republican Distribution of Citizens," National Gazette, 5 March 1792, 242 . 
to human happiness lie vacant." ${ }^{21}$ The occupations Madison indicted above possessed a high division of labor and, therefore, revealed the existence of a subservient wage labor force. These manufacturers usually did not provide necessities, but rather unneeded luxuries. These occupations proved the "least desirable in a free state" because one class of citizens' livelihood depended on the whim of those who consumed the items they produced. Manufacturers were welcome only if they produced necessary goods. Wage labor, however, which large manufacturers depended on, was not to become a mainstay of the America economy, for it threatened the citizen's independence, and hence the nation's republican character.

This, then, provides a rough outline of Madison's ideal society. Based on a thriving, export-oriented agriculture, whose products made their way to Europe in the bottoms of America ships, it manufactured only goods necessary for a society of independent farmers. Republican government provided the foundation. It gave the agriculture-based citizenry the freedom needed to allow industry to flourish and prosperity to grow. Ownership of, and labor on, one's own land secured economic and political freedom, and in turn insured that citizens would guard the society responsible for their freedom. Madison in this way grafted liberal ideas of free, self-seeking individuals to classical 
concepts of property and independence. The outcome was a society which combined liberty and industry with the virtues of republican government.

Unfortunately for Madison, America in the late eighteenth century hardly resembled the society he wanted. The Revolution had done little to remove American commercial dependence on Great Britain. British merchants and ships still dominated American commerce. English manufacturers dumped their goods on American markets without penalty, while American goods entering British ports confronted high duties. Direct trade with the West Indies, the colonies' most lucrative market, remained closed after the Revolution. All the while, the newly independent states seemed more prone to bicker among themselves about commercial regulations than in working to remove the chains tying American trade to British policies. Commercial affairs, Madison worried, demonstrated a "want of concert in matters where the common interest requires it."22 Furthermore, in Madison's opinion, government both under the Articles and for a short time after ratification of the constitution stood on the edge of bankruptcy. Revenue was needed to pay debts and restore honor to the American government. From 1783 to 1795, the struggle to free America from its bondage to Britain and reinvigorate the national

22 Marvin Meyers, The Mind of the Founder, "Vices of the political system of the United States," 85. 
treasury occupied the majority of Madison's time. Despite his approval of free trade, historical circumstances forced him to promote quite different measures to secure his country's commercial independence and financial stability. The fundamental interests of America, he insisted, could not be sacrificed at the altar of free trade. Implementation of free trade, above all, must wait until other nations, especially the British, abandoned their restrictive trade policies. It was also unwise to attempt a policy of free trade when duties on imports provided an attractive method for raising funds to pay off war debts and rescue a floundering treasury. Theoretical ideas had to be adjusted to reality.

Madison, therefore, advocated mercantilistic measures to regulate foreign trade and navigation, with an eye towards breaking the British monopoly and guiding American goods into more "natural channels." He hoped to use commercial discrimination, a form of economic coercion, in place of war to break the British stranglehold. To complement his policies of discrimination, Madison proposed duties on imported goods. To this end, he devised a prudent ideology of political economy to secure, in the long run, free trade and an independent American commerce. The means he advocated mixed together mercantilism and tenets drawn from classical republicanism. Madison meant to realize a liberal objective through reliance on regulatory measures. 
The final success of his policies, however, rested on the virtue of the people. Madison believed the populace would support and endure any hardships caused by his policies because the measures promoted "the public good."

Madison's first attempt came with the Virginia Port Bill, which he introduced in the Virginia House of Delegates in 1784. The bill sought to create established ports of entry in Virginia from which foreign ships were required to discharge and load their cargo. The bill had several purposes. First it was meant to provide Virginia with adequate import and export facilities. ${ }^{23}$ Second, it sought to facilitate collection of duties and reduce smuggling. It would also secure for the Virginia treasury the tribute of thirty or forty percent the importing merchants from Baltimore and Philadelphia had demanded from the state to bring goods there. If Virginia charged the same duties and that money was channeled into the treasury, Madison believed, it would yield a "surplus above all its wants."24 Keeping British captains out of riverside warehouses, however, comprised the most important reason for the bill's introduction. British ships dominated the commerce strewn throughout Virginia's many river ports. The bill intended, above all, to restrict the trade of Great Britain to the

23 At this time Virginians were dependent on importing merchants from those cities, many of whom were British, or who had British sympathies.

24 Irving Brant, James Madison, 2:310. 
same level as other foreign nations, who lacked the means to control as many ports as the British. Furthermore, Madison hoped to prevent the recurrence of the "Scotch Monopoly," which provided initial favors to Virginia planters, but ended with the farmers deeply in debt to British interests. ${ }^{25}$ Restricting the British to certain ports gave local shipping an opportunity to develop in areas that foreign vessels could not go, and freed farmers from the unrepublican specter of debt.

Passing of the Port Bill proved quite a struggle. Ports not named in the bill protested vigorously. Madison hoped to name only Alexandria and Norfolk as established ports of entry, but opposition forced him to add York, Tappahannock and Bermuda Hundred. Discreet advocates of the British monopoly joined forces with merchants interested in maintaining the status quo. They, in turn, enlisted the support of planters who wanted ships at their own wharves. ${ }^{26}$ Madison's reaction to them proved quite instructive.

In the midst of debate an exasperated Madison complained to Jefferson that opponents of the measure attacked the bill for violating the concepts of free trade. These critics charged the bill restricted the gifts nature had bestowed upon Virginia. Madison's scorn for his foes

25 Ibid., 315.

26 Ibid., 315. 
was quite apparent. Opponents, he charged, deluded the people into not seeing the measure's purpose and necessity, the liberation of trade from the British monopoly. "They do not serve the public good," he observed, "only their own interest." 27 Against his critics, Madison maintained that the bulldog grip the British had on American commerce required extraordinary measures. Although a firm advocate of free trade, Madison did not hesitate to abandon the principle when the larger "public good" so dictated. In this respect narrow, individual interest had to be harnessed to the larger interests of the whole. Free trade could not become a reality until American commerce was free and Britain recognized reciprocity in trade. The port bill was Madison's first attempt to realize this goal.

The Port Bill gave Madison only a shallow victory. He had hoped the bill would encourage other states to implement similar policies, but his message went unheeded. A year after the passage of the Port Bill, Madison complained to James Monroe that American "trade was never more completely monopolized by Great Britain...than it is at this moment." 28 Two months later a frustrated Madison wrote again to say he would agree to anything if the state legislatures would just give Congress the power to regulate

27 JM, Madison to Thomas Jefferson, 27 April 1785, $8: 100-102$.

${ }^{28}$ Ibid., Madison to James Monroe, 21 June 1785, 8:307. 
trade. He promised that in order to get the states compliance, he would agree to more frequent Congressional elections, an increase in Congressional numbers, shorter terms for members, and allow no regulatory trade bill to become law unless passed by a majority of the states. Madison felt lawmakers had their priorities backward. They feared giving Congress the power to regulate trade more than the threat presented by the British monopoly, a grievous error to his mind. However, representatives on the state and national level felt otherwise, causing a distraught Madison to plead with them "not [to] sacrifice the end to the means." 29 Having failed to gain regulatory power for Congress under the Articles, Madison urged creation of a new system that had the power to deal with the British menace. The calling of the Constitutional Convention provided Madison the opportunity to correct many flaws he saw in the Articles. The lack of a central power to regulate trade was an, if not the most, important one. Madison confided to Jefferson in March of 1786 that "in fact most of our political evils may be traced to our commercial, as most of our moral to our political." 30 To his mind government's role in a free society consisted of acting as a neutral

\footnotetext{
$8: 334$.

29 Ibid., Madison to James Monroe, 7 August 1785,

30 Ibid., Madison to Jefferson, 18 March 1786, 8:502.
} 
arbiter between its citizens. ${ }^{31}$ Yet he realized a national government must have the power to deal with foreign nations, especially those who applied restrictive and unfair trade practices. The states had failed miserably in their attempt to deal with commercial matters. Madison felt it was time to create a national government, and provide it with power to solve the country's commercial woes. "If it be necessary to regulate trade at all it is necessary to lodge the power, where it can be regulated effectively." ${ }^{32}$ In this regard, Madison was a rarity in Southern politics. Unlike many of his fellow Virginians, he trusted a national government to draft trade regulations that would benefit all. ${ }^{33}$

In the Constitutional Convention the discussion of the proposed government's power brought major disagreements, both sectional and ideological, to the surface. During the discussion of duties and impost regulation, Madison's fellow Virginian, George Mason, urged the Convention to incorporate

31 On government acting as a neutral arbiter between interests see Meyers' Mind of the Founder, 96, which contains an April 16, 1787 letter of Madison's to Washington. In it Madison revealed that republican governments to date had lacked "some disinterested and dispassionate umpire" to settle disputes. See also ibid., 244, for Madison's article "On Property" in which he concludes that a just government is one which "impartially secures to every man whatever is his own." The emphasis is Madison's. In addition consult Isaac Kramnick's "The 'Great National Discussion': The Discourse of Politics in 1787," 332, especially pages six and seven. Kramnick makes an argument similar to the one outlined above.

32 JM, Madison to Monroe, 7 Aug. 1785, 8:333.

33 Ibid., Editorial Note, 8:406-408. 
into the Constitution a resolution forbidding the new government to tax exports because such a duty would fall heaviest on the South. Madison quickly challenged Mason. He asserted that the new government should have the power to tax exports. This power should not be yielded for it provided the government with a possible source of revenue. Furthermore, it was only right that southerners bear the lion's share of an export tax. Madison believed funds raised through such a tax were necessary to finance naval protection of ships carrying mostly southern goods. ${ }^{34}$ Five days after his rebuttal of Mason, Madison again argued for the power to tax exports. He claimed export duties "may not be expedient at present", but like imports they may have to be regulated in order to gain revenue, encourage domestic manufacturers, and, most importantly, procure "equitable regulations from other nations." ${ }^{35}$ The seeds of Madison's commercial discrimination policy can be seen in this remark made during the Constitutional Convention. The policy would blossom and then wither during Madison's years as a Congressman.

Despite Madison's failure to secure Congressional power to tax exports, the new Constitution did give Congress much

34 James Madison, Notes, 467-468.

35 Ibid., 499-500. Later that same day a motion passed which said that no tax should be laid on exports. Virginia voted with the majority with two dissenting voices, Washington's and Madison's. 
greater power to regulate trade than had the Articles. Once passage of the Constitution was assured and after Madison's election to a seat in the House, he immediately renewed his effort for regulatory measures.

During the first session of Congress in 1789 Madison proposed impost duties to raise money for the treasury. In the debate, Madison urged his fellow Representatives to look after local interests, but also to consider "the general interest of the union." ${ }^{36}$ He criticized representatives who proposed a drop in impost rates on goods consumed primarily in their constituency. All, he insisted, must pay an equal share, for republican government was based on the premise that it "will equally effect all."17 Madison rebuked those who argued that a duty on Jamaican rum would cause people to start smuggling the spirit as they had during British rule. He could not believe "the virtue of our citizens is so weakly fortified." ${ }^{38}$ He defied comparisons between an unfair British tax and a just American one. The people would comply because they saw a just end for the measure, stability for the Treasury. While generally pleased with the outcome of impost rates, Madison criticized the inability of some Representatives to look

${ }^{36}$ JM, Congressional Speech, 9 April 1789, 12:70.

37 Ibid., Congressional Speech, 29 April 1789, 12:119120 .

38 Ibid, Congressional Speech, 24 April 1789, 12:108. 
beyond the scope of their local interests. Such attitudes caused the duties to lean toward local interests "at the expense of the general interest." 39 The debates over duties clearly revealed the classical side of Madison, one concerned deeply with the "public good", and one willing to enact regulatory measures in order to secure the interests of all.

Emotions ran high as Congress debated the second half of Madison's revenue making measure, which called for a tonnage duty, discriminating between ships from nations who had a commercial treaty with America, and those who did not. As Drew McCoy has pointed out, the purpose of the bill centered on removing British domination through discriminatory commercial legislation. ${ }^{40}$ It provided a prime example of Madison adopting mercantilist measures to secure free trade and tying, ultimately, the success of his measures to the citizens' virtue and frugality. That is to say, classical ideas provided the means to a liberal end, free commerce. In the test of wills between the British and American people, Madison believed, furthermore, the republican character of the latter's people insured they would endure hardship and deprivation of a trade war better than their British counterparts.

In introducing the measure on April 8, 1789, Madison

39 Ibid., Madison to Tench Coxe, 24 June 1789, 12:257.

40 Drew R. McCoy, The Elusive Republic, 138. 
outlined several purposes. The tonnage duties, he argued, would reduce the imbalance of trade with Great Britain. While American ports remained open to all English goods, Britain refused to recognize a reciprocal policy towards the United States. As a result of the trade imbalance caused by this policy, commerce between the two nations exceeded "what may be considered its natural boundary."41 British trade policies killed competition and allowed British imports to exceed American exports by large amounts. Once natural competition resumed, or a set of equally restrictive trade measures were enacted, the ratio of imports to exports would balance out. Britain, in addition, had continued to close the West Indies to direct American trade, one of the most natural and important outlets for American goods. Thus, according to Madison, until the British retracted their extreme mercantilist policies, America must adopt the same measures to protect its own interests. Throughout, Madison maintained his adherence to free trade, but English policies forced him to propose measures designed to restrict the British, and secure American commercial independence. ${ }^{42}$ $12: 269$.

${ }^{41}$ JM, Madison to Thomas Jefferson, 30 June 1789,

42 Ibid., Congressional Speech, 21 April 1789, 12:102. The idea that commercial discrimination could bring Britain to its knees was not new. McCoy, in the Elusive Republic, 143, points out that Adam Smith in the Wealth of Nations mentioned the British economy was vulnerable to the type of scheme that Madison introduced fifteen years later. Whether Madison got his idea from the Wealth of Nations, remains unclear. However, Madison had read Smith's book. While in 
The Tonnage discrimination bill also intended to encourage American shipping. According to Madison, ships built and owned by Americans would pay a smaller duty than foreign ships. Southerners charged that higher duties placed too great a burden on them. Madison replied that the measures would hurt the south only for short time, until American shipping had grown enough to handle the bulk of Southern produce. ${ }^{43}$ The end result would benefit "the common good" of the entire nation, releasing American farmers from their dependence on British bottoms, cheapening the transportation of American goods, and providing protection for the coast. The small sacrifice the South had to endure, he argued would, in the long run, provide benefits run not only for the section, but for the entire nation as well. ${ }^{44}$ By acting for the common good now, citizens could at a later date enjoy the freedom to pursue their interests.

In addition, Madison believed than an enlarged American shipping fleet held out other advantages, above all the opening of the French market for American goods. Madison's leaning towards France in foreign economic policy

Paris Jefferson received a letter from Madison asking to buy for him a collection of tracts on French Economics that were "much referred to by Smith on the wealth of nations." JM, Madison to Jefferson, 27 April 1785, 8:266.

43 Ibid., Congressional Speech, 5 May 1789, 12:134-135.

44 Cathy Mason and Peter Onuf, "Toward a Republican Empire," 515. 
antedated the Revolution. ${ }^{45}$ Looking to break the English monopoly by also exploiting other markets, his proposed tonnage duties would invigorate trade with an ally depressed "beyond what nature deserves."46 Even the small amount of commerce that made its way to France went via England, proving to Madison that "American commerce flows in an improper channel" and demanded rectification. ${ }^{47}$ Elimination of artificial obstructions between original production and final consumption created a truly "natural economy." ${ }^{48}$ Madison confided a similar thought in a letter to Jefferson. "American trade will not be in its proper channels until it should flow directly to the countries making the exchange." 49

Discriminatory tonnage duties, then, would hinder British mercantile interests, force reciprocity, break down barriers that kept American commerce from flowing (according to Smithian laws of political economy) to its most "natural" markets, and promote the growth of an American fleet. American shipping would allow its citizens to take advantage

45 Madison's bias towards France is further evidenced by his decision in 1792 to accept an offer of citizenship granted him by the French Government.

${ }^{46}$ JM, Congressional Speech, 4 May 1789, 12:129.

47 Ibid., Madison to Jefferson, 30 June 1789, 12:269.

${ }^{48}$ Cathy Mason and Peter Onuf, "Toward a Republican Empire," 510 .

49 JM, Madison to Jefferson, 30 June 1789, 12:269. 
of other markets, especially France, and at the same time increase the nation's safety and economic independence. ${ }^{50}$

If Madison's goals seemed admirable, many questioned the effectiveness of commercial discrimination and the ability of the republic to withstand a trade war with Great Britain. Would discriminatory tonnage rates, some asked, really free American trade and provide the initiative for development of a commercial fleet? What adverse effects, asked others, would result if his plan failed? Northeastern commercial interests, in particular, opposed Madison's measures. They worried that Great Britain might respond by cutting off all trade with the United States. America, they held, was too dependent on Great Britain to risk offending her.

Madison, on the other hand, saw things differently. Great Britain needed American trade more than America needed Great Britain's. He had no fear of British retaliation. "Her interests can be mortally wounded, while ours are invulnerable." 51 According to Madison, America supplied agriculture products to the British Empire, necessities of life, while Americans received in return superfluities, manufactured luxury goods. British manufacturers and laborers depended on American consumers and if an economic war occurred, American consumers could, by adopting frugal

50 Drew R. McCoy, The Elusive Republic, 125.

51 JM, Congressional Speech, 4 May 1789, 12:127. 
habits and ceasing to buy British goods, throw English laborers out of work. By the same token, the lack of American foodstuffs would cause food shortages in portions of the British Empire, eventually forcing the British to accede to the republic's demands. ${ }^{52}$ The surplus produced by independent American farmers, furthermore, would always secure a permanent market, unless the people of a European nation decided to stop eating. Clinching the case for Madison was his belief that "the produce of this country is more necessary to the rest of the world than that of other countries..." 53

In the event of a trade war with Great Britain, Madison similarly held, these natural advantages, combined with the virtue of the American people, insured victory. Knowing that the struggle was for the "public good" the citizens of the United States would endure the burdens of an embargo better than their British counterparts. ${ }^{54}$ Mercantilist measures united with the virtue and frugality of the American people formed the basis of Madison's plan to liberate the commerce of his nation. But despite his eloquent arguments for discriminatory tonnage duties, the Senate, in June of 1789 , struck out the clause that

52 Drew R. McCoy, The Elusive Republic, 125, 140.

53 JM, Congressional Speech, 26 April 1789, 12:112.

54 Marvin Meyers, The Mind of the Founder, "Political Observations," 2 April 1795, 294. 
differentiated between nations in treaty with the U.S. and nations who were not. Fear of the British retaliation proved too strong, and commercial discrimination died.

Defeated in his first attempt, Madison resurrected his discriminatory policy four years later when British actions against American commerce again aroused public passions. Looking again to secure a doctrine of free trade, he advocated the same type of regulatory measures and stressed reliance on the republican character of the citizenry. When England and France once again turned to military force to settle their differences in 1790s, the conflict provided Madison with his opportunity.

As conflict between France and England began anew, Britain insured that relations with the U.S. would also flare up by adopting policies that struck hard at American commercial interests. France's fear that the West Indies would be blockaded by the British led them to open the French West Indies to "neutral" American ships, which had not been the case before the war. London's attempt to block the opportunistic French ploy led to passage of the odious Orders in Council. Passed in June and November of 1793, the orders were immediately provocative. The June order allowed the British to seize and purchase the cargoes of neutral ships bound for French ports, or those under French control. While it hurt the pride of American ship captains to have their vessels arbitrarily boarded and searched by British 
naval officers, no monetary losses took place. The second, however, gave British captains the authority to detain and confiscate neutral ships carrying the produce of a French colony, or supplies used by such a colony. In short order, the British seized about three hundred vessels, throwing their crews into foul jails or "inviting" them to join the British Navy.

To Madison it was apparent that the havoc the orders in Council played with American trade in the West Indies manifested the "ill will and contempt of Great Britain towards us."55 A diplomatic agreement remained out of reach. The missions of John Adams and Thomas Pinckney had failed to secure any good. American diplomats sent to London were frozen out, making them, according to Adams' dispatches, "as insignificant here as you can imagine."56 To change the intolerable attitude of the British required harsh measures.

Acting to implement Jefferson's 1793 report on the state of American Commerce in Foreign Countries, Madison introduced in the House seven resolutions designed to create a policy of commercial discrimination. His underlying assumption was the same as 1789 , and he relied on the same arguments, with one new addition.

55 IM, Madison to Horatio Gates, 24 March 1794, 15:287.

56 John Adams to John Jay, quoted in Thomas A. Bailey, A Diplomatic History of the American People, 8 th edition, (New York: Appleton-Century-Crofts, 1969), 55. 
Discrimination, Madison again argued, would work because Great Britain was more dependent on the United States than America was on England. Discrimination would also succeed because of the virtue and frugality of the American people. ${ }^{57}$ Finally, Madison's prudent policy provided a middle way. It preserved the national honor by acting against Great Britain, but did so short of war, something dangerous to republican government and something for which America was ill-prepared.

In considering the import and tonnage duties to be placed on foreign vessels originating from a country who did not have a commercial treaty with the United States, Madison again urged his fellow Congressman to remember that "small local sacrifices must be made to obtain a greater good." 58 The higher the duties and tonnage fees the clearer the message sent to Great Britain.

This time discussion of import and tonnage duties did not produce the heated debate they had in 1789; instead Congressmen clashed mainly over the practicality of Madison's proposals. Massachusetts Representatives Samuel Dexter and Fisher Ames, along with Thomas Fitzsimmons of

57 As he had in 1789, Madison argued for discrimination because of the benefits American shipping would receive. Yet he used this line of reasoning less than in 1789, possibly because Madison did not want to encourage Federalist ideas that called for a buildup of the American Navy. See JM, Congressional Speech, 3 January 1794, 15:169.

${ }^{58} \mathrm{JM}$, Congressional Speech, 6 Feb. 1794, 15:248. 
Pennsylvania and William L. Smith of South Carolina, proved Madison's most vocal opponents. They held to the Federalist Iine that discriminatory measures would cause a trade war with Great Britain. Such an event, they insisted, would cripple American trade, but cause little damage to the British Empire.

Madison, in response, argued that something had to be done to the British. The world would be a wonderful place if nations, like the British, tore down their trade barriers. However, America could not adopt a policy which did not exist anywhere else. ${ }^{59}$ The trade imbalance and British high handed seizures on the open sea had to be stopped.

In 1794, as in 1789, Madison pointed out that England's economy was weak because it rested on an unnatural foundation. America's advantages over Britain resulted from the country's natural economy and the character of its people. Great Britain sent the U.S. "superfluities" or luxury goods. As a result, the British economy was dependent on the whims of her consumers.

By 1794 Madison believed he had empirical evidence for these perceptions, gleaned from his study of the plight of British manufacturing in 1792. His 1792 article for the National Gazette, "Fashion" dealt with this topic. In it

59 Ibid., Congressional Speech, 14 January 1794, $15: 182$. 
Madison discussed a petition the Prince of wales had received from the buckle manufacturers in Birmingham, Wassal and Wolverhampton. According to the petition, their industry stood on the verge of ruin because a change of fashion had caused people to start using shoestrings and slippers. As a result of this "whim" twenty thousand people lost their jobs. The manufacturers implored the Prince to help change fashion back in their favor by ordering his staff to wear buckles.

To Madison the story had immediate consequences for American foreign policy. The plight of the manufacturers and their workers, whose employment came from the "precarious source of fashion and superfluity," provided both a lesson and an opportunity for Americans. ${ }^{60}$ The lesson was simple: the more people a nation employed in trades dependent on external commerce, the more it became dependent on the caprice of other nations. Madison lamented the fate of the British worker. "Can any despotism be more cruel than a situation, in which the existence of thousands depends on one will, and that will on the most slight and fickle of all motives." ${ }^{61}$ Equally important was the opportunity the story pointed to: an economy based on manufacturing, which heavily depended on fashion, was, $14: 258$.

60 Ibid., "Fashion," National Gazette, 20 March 1792, 61 Ibid., 258. 
Madison believed, susceptible to the measures he proposed to Congress in 1794. The unnatural British economy was vulnerable because it was dependent. Its foundation rested on laborers engaged in wage labor, who had, therefore, neither economic nor political liberty. Consequently, their existence depended on the manufacturers for whom they worked, who in turn, relied on habits of fashion and the consumption patterns of foreign nations. A change in fashion or a decline in consumption threatened the whole false structure.

Britain's former colonies, to the contrary, exported "chiefly the necessaries of life, or raw materials." American goods always secured a sure market. America, moreover, could do without goods it received from other countries "or produce substitutes." 62 If forced into a contest of self denial to protect her national interest, "our country may make her enemies feel the extent of her power." 63 In an economic war, he granted, America would not emerge unscathed, but if the "virtue and temper of our fellow citizens were not mistaken, the experiment would find

62 Ibid., Congressional Speech, 3 January 1794, 15:169. Madison also saw a golden lining in his discriminatory policy for manufacturers. He reasoned that if you discouraged the manufacturing of one nation you might build up your own, and, in fact, encourage manufacturers to move to the America, whose burgeoning country might provide a lucrative market for the manufacturers. Consult JM, Congressional Speech, 14 January 1794, 15:183.

63 Ibid., 3 January 1794, 15:169. 
in them a far greater readiness to bear it." 64 Unlike a military contest, an economic conflict allowed America to fight from a position of strength.

Another benefit of Madison's policy was, then, the ability to avoid military war. By 1794, Britain's arbitrary seizures had enraged many to the point of war. Even the ardent Anglophile, Alexander Hamilton, considered Britain's actions "atrocious" and advised President Washington to prepare for war. ${ }^{65}$ Madison wanted to punish the British, but avoid martial conflict.

Madison, like all people influenced by classical republicanism, knew that "of all the enemies to public liberty war is, perhaps, the most to be dreaded."66 It provided the impetus for the development of armies, (which Federalists were attempting to raise at that time), meant higher taxes and increased debt, all instruments of corrupt governments intent on tyrannizing the people. To Madison's mind, his prudent measures had the advantage of avoiding war and fighting a battle on terms which gave America a decided edge. In military matters, he advised, England "is an overmatch for us." However, in commercial operations, "here $15: 189$.

64 Ibid., Congressional Speech, 14 January 1794,

65 Thomas A. Bailey, A Diplomatic History of the American People, 73 .

${ }^{66}$ Marvin Meyers, Mind of the Founder, "Political Observations," 20 April 1795, 15:287. 
the United States are unquestionably an over-match for Great Britain."67 Logically, then, the United States stood a better chance of forcing concessions through commercial discrimination than by use of military force.

Madison's proposals met with qualified support throughout the nation. Support came from most parts of the country. Three American ship captains, languishing in a Kingston, Jamaica jail sent Madison a letter supporting his resolutions. ${ }^{68}$ The letter made its way into many newspapers. The momentum commercial discrimination had gained, however, quickly waned in early March of 1794, when the British seized and condemned one hundred American vessels in the West Indies. Sterner measures were needed, something even Madison admitted to Jefferson when he reported the newest British outrage. ${ }^{69}$ In response, a thirty day embargo was passed by both Houses. The decision by Washington to send a diplomatic mission headed by John Jay to solve the crisis followed on the heels of the embargo. Jay's mission, for all practical purposes, ended

67 Ibid., 296.

68 JM, Madison from Joshua Barney and Others, 13 March 1794, 15:281-282. The popularity of Madison's proposals can also be assessed by the fate dealt to opponents of his measures. Representatives Fitzsimmons and Dexter, two of the more outspoken opponents, were defeated in their reelection bid, along with several other Congressmen, primarily for their attacks on Madison's policy. See JM, Editorial Note, 15:148-149.

69 Ibid., Madison to Thomas Jefferson, 12 March 1794, 
Madison's last attempt as a Congressman to implement his policy of commercial discrimination.

Despite the fact that Madison's ideas never came to fruition until Jefferson's presidency, a study of it reveals the sui generis nature of his ideology. It shows Madison reconciled individual interest with the public good. In this regard, a summary of his political ideology is found in some comments Madison made to James Monroe in 1785. He confided to his friend that he wished for a system of free trade, but that before such a reality could occur America must first climb out of debt and assure that other nations concurred in the policy. ${ }^{70}$ The comments reveal, on one hand, Madison's wish to free the individual to pursue his self interest. As he noted in another context, "the great principle of interest is a leading one with me." ${ }^{71}$ But by the same token Madison understood circumstances would arise in which the national interest called for firm regulatory measures and required the citizenry to act virtuously.

Thus he abandoned neither virtue nor interest, but blended them together. While historians today continue to present classical and liberal republican ideologies as antagonistic to each other, Madison's prudent political economy provides a clear exception. He felt the people had an "enlightened self interest" which allowed them individual

70 JM, Madison to Monroe, 21 April 1785, 8:333.

71 Ibid., Congressional Speech, 21 April 1789, 12:99. 
initiative, but in times of crisis prompted them to sacrifice their interests to preserve the government that allowed individual freedom. Without liberty virtue could not exist, and neither could liberty without virtue. One provided freedom, the other protected it. Madison's Port Bill, his arguments before and during the Constitutional Convention for extensive Congressional powers to regulate trade, and his policy of commercial discrimination, arose from his belief that they "promoted the public good." They fostered the general good because they secured American commercial independence, promoted individual interest by creating a system of free trade, and provided a means of avoiding war. Madison's belief that the people would abide by and even support such measures, despite the deprivation they suffered, shows how deeply classical republicanism affected him. Yet Madison's end was a liberal one. Once reached, this goal would leave the citizens free from commercial regulations, measures Madison termed himself as "generally unjust, oppressive and impolitic."72 A prudent middle way existed between virtue and interest. Exploration of this middle way illustrates Madison's ability to consolidate fibers from different ideologies and weave them into a system uniquely his own.

72 Ibid., Congressional Speech, April 9, 1789, 12:71. 


\section{CHAPTER V}

\section{CONCLUSION}

In early 1792 Madison published an article on the "The Spirit of Governments" in the National Gazette. In it he reminded his audience that "no government is perhaps reducible to a sole principle of operation." ${ }^{1}$ Even in societies where the previous statement seemed erroneous, he noted, oftentimes "different [and] heterogeneous principles mingle their influence..."2 Historians of Madison's thought have, unfortunately, ignored these comments, focusing instead on explaining his ideas through singular paradigms built on narrow slices of his writings. This study, on the contrary, holds that a clearer understanding of Madison emerges if one explains his thought through more than one paradigm or section of his writings.

Reducing the mind of Madison to "a sole principal of operation" slights the breadth of his study and experiences, and discounts the supple nature of his intellect. His education, writings, personal library and political career reveal the presence of both classical and liberal

1 Marvin Meyers, The Mind of the Eounder "The Spirit of Governments, " National Gazette, February 20, 1792, 239.

2 Ibid., 239. 
convictions and concerns. When he referred to political theorists in his writings from 1751-1795, Madison mentioned Locke and Montesquieu most often. His comment to Jefferson in 1825 that the writings of Sidney and Locke provided indispensable information about the cause of liberty was not accidental. ${ }^{3}$ In referring to these two authors-representatives of republican and liberal ideologies, respectively--Madison testified to the influence of the two traditions upon him.

Narrow interpretations of Madison have encouraged narrow readings of Madison. Critics and even admirers of Madison view The Federalist as the Alpha and Omega of his thought. For many it remains a standard of American political theory. Yet the high regard The Federalist eventually garnered never permeated Madison's mind. Both during and after completion of it, he sought to keep his role secret. Even his best friend, Jefferson, did not learn of his role in the project until after ratification of the Constitution. By that time the essays were published in a two volume set, and Jefferson had already learned of his friend's participation from other sources." Madison revealed his authorship to Jefferson in late 1788. He referred to it in a casual way, as something trivial that had slipped his mind. "Col. Carrington," he wrote:

3 Ibid., Madison to Jefferson, 8 February 1825, 444.

4 Drew R. McCoy, The Last of the Fathers, 47. 
tells me he has sent you the first volume of the federalist, and adds the $2 \mathrm{~d}$. by this conveyance. I believe I never have yet [the rest of the quote is in code] mentioned to you that publication. It was undertaken last fall by Jay, Hamilton and myself. The proposal came from the two former. Though carried in concert the writers are not mutually answerable for all the ideas of each other there being seldom time for even a perusal of the pieces by any but the writer himself. ${ }^{5}$

Madison never developed the attachment to The Federalist that others, including Jefferson, felt. ${ }^{6}$ If Madison referred with pride to any of his writings it was "Memorial and Remonstrance." One scholar, John Zvsper, has argued that much of the writings of Madison-Publius was just rhetoric, implying that Madison never really believed much of the doctrine contained in The Federalist. ${ }^{7}$ While somewhat overstated, Zvsper's comments rightly emphasize that there is more to Madison's thought than The Federalist. There remains, then, the need for more study of Madison's political theories. This thesis has attempted to explain a slice of his doctrines, and also suggest a new way to study him. Social historian Victoria Bonnell has noted that in analyzing complex events "a single theory, however

${ }^{5}$ JM, Madison to Jefferson, 11 August 1788, $11: 227$.

6 Yet it must also be noted that Madison and Jefferson included The Federalist in their list of textbooks for law students at the University of Virginia. Along with The Federalist, they included the Declaration of Independence, the Virginia Report of 1799, and Washington's Inaugural and Farewell speeches, a rather curious assortment of sources. Marvin Meyers, The Mind of the Founder, 442-446.

7 John Zvsper, "The Madisonian Systems," Western Political Quarterly 37.2 (1984), 236-256. 
rich and multi-variate, will seldom suffice. Complex events usually have multiple causes..." ${ }^{8}$ To paraphrase Bonnell, one might argue similarly that in analyzing complex individuals like Madison, no single theory, intellectual paradigm or source, no matter how profound, will suffice. Complex figures like Madison were influenced by multiple theories.

Perhaps Peter Onuf is right. Scholars grew discouraged about the scholarship of the early republic which came from the bicentennial because they missed seeing how recent works exposed the complexity of the founding period. Instead, they eagerly awaited the discovery of a new paradigm hoping it would, through a single interpretative lens, neatly explain the Constitutional era. The answer, however, may lie so close to us that, like the proverbial snake, it waits to bite. A thorough study which examines all the sources, remains faithful to the historical context of events, and which at its inception does not limit itself to one explanatory paradigm, may eliminate much of the ambiguity which surrounds the founding period, and, more to the point, the thought of the nation's the least known but "most powerful and probing intellect," 9 James Madison.

${ }^{8}$ Victoria Bonnell, Roots of Rebellion: Worker's Politics and Organizations in St. Petersburq and Moscow, 1900-1914 (Berkeley: University of California Press, 1983.)

9 Jack N. Rakove, James Madison: And the Creation of the American Republic (Glenview, IL: Little, Brown Higher Education, ) 1990, 181 . 
WORKS CONSULTED

\section{Primary Sources}

Farrand, Max, ed. The Records of the Federal Convention of 1787. rev. ed. 4 vols. New Haven: Yale University Press, 1937 .

Locke, John. Two Treatises of Government. ed. Peter Laslett. Cambridge: Cambridge University Press, 1960.

Madison, James. The Writings of James Madison Comprising His Public Papers and His Private Correspondence. Gaillard Hunt, ed. 9 vols. New York: G.P. Putnam Sons, 1900-10.

- Alexander Hamilton, and John Jay. The Federalist Papers. New York: Mentor Books, 1961.

- "Autobiography," William and Mary Quarterly. 2.1 (April, 1945,) 191-209.

- Notes of Debates in the Federal Convention of 1787 . Introduction by Adrienne Koch. New York: W.W. Norton \& Company, 1966.

- The Papers of James Madison. William M.E. Rachal and Robert A. Rutland. 15 vols. Chicago: University of Chicago Press, and Charlottesville, VA: University of Virginia Press, 1962-1985.

- The Papers of James Madison. Presidential Series. Thomas Mason and Robert A. Rutland, et.al. eds. 2 vols. Charlotesville: University of Virginia Press, 1984.

Meyers, Marvin. The Mind of the Founder: Sources of the Political Thought of James Madison. Indianapolis: Bobbs-Merrill, 1983.

Montesquieu, Baron de. The Spirit of the Laws. ed. Franz Neumann, trans. Thomas Nugent, 2 vols. New York: Hafner Publishing, 1966.

Monographs

Alley, Robert S., ed. James Madison: On Religious Liberty. Buffalo: Prometheus Books, 1985. 
Appleby, Joyce. Economic Thought and Ideology in Seventeenth Century England. Princeton: Princeton University Press, 1978 .

- Captialism and the New Social Order. New York: New York University Press, 1984.

Bailey, Thomas. A Diplomatic History of the American People. 8th edition New York: Appleton-Century-Crofts, 1969.

Bailyn, Bernard. The Ideological Origins of the American Revolution. Cambridge: Harvard University Press, 1967.

Beeman, Richard \& et. al., eds. Beyond Confederation: Origins of the Constitution and American National Identity. Chapel Hill: University of North Carolina Press, 1987 .

Banning, Lance. The Jeffersonian Persuasion:Evolution of a Party Ideology. Ithaca, NY: Cornell University Press, 1978 .

Beard, Charles. An Economic Interpretation of the Constitution. New York: MacMillian, 1913.

Billington, Ray Allen. The Protestant Crusade, 1800-1860. New York: Rhinehart and Company, Inc., 1952.

Borden, Michael. Jews, Turks, and Infidels. Chapel Hill: University of North Carolina Press, 1984.

Brant, Irving. James Madison. 6 vols. Indianapolis: Bobbs Merrill, $1941-61$.

- The Fourth President: A Life of James Madison.

Indianapolis: Bobbs Merrill, 1970.

- James Madison and American Nationalism. Princeton: Van Nostrand, 1968.

Burns, Edward McNall. James Madison: A Philosopher of the Constitution. rev. ed. New York: Octagon Books, 1968.

Dahl, Robert. Pluralist Democracy in the United States. Chicago: Rand McNally, 1967.

Diggins, John P. The Lost Soul of American Politics: Virtue, Self Interest, and the Foundations of Liberalism. New York: Basic Books, 1984 .

Ellis, John Tracy. American Catholicism. Chicago: University of Chicago Press, 1956. 
Epstein, David E. The Political Theory of The Federalist. Chicago: Chicago University Press, 1984.

Furtwangler, Albert. The Authority of Publius. Ithaca, NY: Cornell University Press, 1984.

Isaac, Rhys. The Transformation of Virginia. Chapel Hill: University of North Carolina Press, 1982.

Jensen, Merrill. The New Nation: A History of the United States During the Confederation. New York: Alfred A. Knopf, 1950 .

Karp, Abraham, ed. The Jewish Experience in America. 3 vols. New York: Ktav Publishing House, 1969.

Ketcham, Ralph. James Madison: A Biography. New York: MacMillian, 1971.

Koch, Adrienne. Madison's Advice to My Country. Princeton: Princeton University Press, 1966.

- Jefferson \& Madison: The Great Collaboration. New York: Alfred A. Knopf, 1950 .

McCoy, Drew. The Elusive Republic: Political Economy in Jeffersonian America. Chapel Hill: University of North Carolina Press, 1980 .

- The Last of the Fathers: James Madison and the Republican Leqacy. Cambridge: Cambridge University Press, 1989.

Peterson, Merrill, ed. James Madison: A Biography in His Own Words. New York: Harper \& Row, 1974 .

Pocock, J.G.A. The Machiavellian Moment: Florentine Political Thought and the Atlantic Republican Tradition. Princeton: Princeton University Press, 1975.

Rakove, Jack. James Madison: And the Creation of the American Republic. Glenview, IL: Little, Brown Higher Education, 1990 .

Riemer, Neal. James Madison: Creating the Consitution. Washington D.C.: Congressional Quarterly, 1986. 
Robbins, Caroline. The Eighteenth Century Commonwealth Man: Studies in the Transmission, Development, and Circumstance of English Liberal Thought From the Restoration of Charles II until the war with the Thirteen Colonies. Cambridge: Harvard University Press, 1959 .

Rossiter, Clinton. 1787: The Grand Convention. New York: MacMillian, 1966.

Rutland, Robert A. James Madison: The Founding Father. New York: MacMillian, 1987.

Schumate, Daniel $T .$, ed. The First Amendment: The Legacy of George Mason. Fairfax, VA: George Mason University, 1987 .

Smith, James Allen. The Spirit of American Government: A Study of the Constitution. New York: MacMillian, 1907.

Watts, Stephen. The Republic Reborn: War in the Making of Liberal America, 1790-1820. Baltimore: John Hopkins University Press, 1987.

Wiley, Basil. The Seventeenth Century Background. (New York: Doubleday, 1935 .

Wills, Gary. Explaining America: The Federalist. New York: Penguin Books, 1981 .

Wood, Gordon S. The Creation of the American Republic, 17761787. New York: W.W. Norton \& Company, 1969.

Articles

Adair, Douglass. "The Tenth Federalist Revisited," William and Mary Quarterly. 8.1 (January 1951): 467-487.

- "That Politics May Be Reduced to Science: David Hume, James Madison and the Tenth Federalist," Huntington Library Quarterly. 20.4 (August 1957): 343360 .

Agresto, John. "A System Without Precedent: James Madison \& the Revolution in Republican Liberty," South Atlantic Quarterly 82.2 (1983): 129-144.

. "Liberty, Virtue, and Republicanism, 1776-1787," Review of Politics. 39.4 (October 1977): 473-504.

Alley, Robert $S$. "On Behalf of Religious Liberty: James Madison's Memorial and Remonstrance," This Constitution. 12 (December 1987): 26-33. 
Appleby, Joyce. "Republicanism in Old and New Contexts," William and Mary Quarterly. 43 (January 1986): 20-34.

. "Republicanism and Ideology," American Quarterly.

37.4 (1985): 461-473.

- "Commercial Farming and the 'Agrarian Myth' in the Early Republic," 68.4 (March 1982): 833-849.

Banning, Lance. "James Madison and the Nationalists, 178083," William and Mary Quarterly. 40 (April 1983): 227255 .

- "Jefferson Ideology Revisited: Liberal and Classical Ideas in the New American Republic," William and Mary Quarterly. 43 (January 1986): 1-17.

- "The Moderate as Revolutionary: An Introduction to Madison's Life. Quarterly Journal of the Library of Congress. 37.2 (1980): 162-175.

"The Hamiltonian Madison: A Reconsideration," Virginia Magazine of Biography and History. 92.1 (1984): 2-28.

Bourke, Paul F. "The Pluralist Reading of James Madison's Tenth Federalist," Perspectives in American History. 9 (1975): 271-95.

Branson, Roy. "Madison and the Scottish Enlightenment," Journal of the History of Ideas. 40.2 (1979): 235-50.

Brant, Irving. "Madison's Separation of Church and State," William and Mary Quarterly. 8 (1951): 1-24.

Carey, George W. "Separation of Powers and the Madisonian Model: A Reply to the Critics," American Political Science Review. 72 (March 1978): 151-164.

Coleman, Frank M. "The Hobbesian Basis of American Constitutionalism," Polity. 7.1 (1974): 57-89.

Coniff, J. "Obsolensce of General Will; Rousseau, Madison and the Evolution of Republican Thought," Western Political Quarterly. 28.1 (1975): 32-58.

- "The Enlightenment and American Political Thought: A Study of the Origins of Madison's Federalist No. 10," Political Theory. 8.3 (September, 1981): 381-402. 
Corwin Edward S. "The Progress of Constitutional Theory between the Declaration of Independence and the Meeting of the Philadelphia Convention," American Historical Review. 30 (1925): 513-26.

Dante, Cermino. "James Madison, Philosophical Pluralist," Modern Age. 27.1 (1983): 42-49.

Davidson, Phillip G. "Virginia and The Alien and Sedition Laws," American Historical Review. 36 (1931): 336-42.

Dewey, Donald O. "James Madison Helps Clio Interpret the Constitution," American Journal of Legal History. 15.1 (1971): 38-55.

Diamond, Martin. "Democracy and The Federalist: A Reconsideration of the Framer's Intent," American Political Science Review. 53 (March 1959): 52-68.

Diggins, John P. "Republicanism and Progressivism," American Quarterly. 37.4 (Fall 1985): 572-598.

- "Power and Authority in American Politics," American Historical Review. 86.4 (October 1981): 701-730.

Einhorn, Lois J. "Basic Assumptions in the Virginia

Ratification Debates: Patrick Henry, vs. James Madison on the Nature of Man and Reason," Southern Speech Communication Journal. 46.4 (1981): 327-340.

Erler, Edward J. "The Problem of Public Good in The Federalist," Polity. 13.4 (1981): 649-667.

Fay, C.R. "Adam Smith, America, and the Doctrinal Defeat of the Mercantile System," Quarterly Journal of Economics. 48 (1933-1934): 304-316.

Hobson, Charles F. "The Negative on State Laws: James Madison, The Constitution, and the Crisis of Republican Government," William and Mary Quarterly. 36.2 (1979): 215-239.

Howe, David W. "The Political Psychology of The Federalist," William and Mary Quarterly. 44.3 (July 1987): 485-509.

Hutson, James H. "Country, Court \& Constitution: AntiFederalism and the Historians," William and Mary Quarterly. 44.3 (July 1981): 337-368. 
Kenyon, Cecelia M. "Men of Little Faith: The AntiFederalists on the Nature of Representative Government," William and Mary Quarterly 12.1 (January 1955): 3-43.

Kerber, Iinda. "The Republican Ideology of the Revolutionary Generation," American Quarterly. 37.4 (Eall 1985): 474495 .

Kessler, Sanford. "Locke's Influence on Jefferson's Bill for Establishing Religious Freedom," Journal of Church and State. 25.2 (1983): 231-252.

Ketcham, Ralph. "Publius: Sustaining the Republican Principle," William and Mary Quarterly. 44.3 (July 1987 ) : $576-582$.

- "James Madison and the Nature of Man," Journal of the History of Ideas. 19 (1958): 62-76.

Kloppenberg, James $H$. "The Virtues of Liberalism:

Christianity, Republicanism, and Ethics in Early American Political Discourse," Journal of American History. 74 (June 1987): 9-33.

Kramnick, Issac. "The 'Great National Discussion,' : The Discourse of Politics in 1787," William and Mary Quarterly. 45 (January 1988): $3-\overline{32}$.

- "Republican Revisionism Revisited," American Historical Review. 87.3 (June 1982): $629-664$.

Lawler, Peter Augustine. "James Madison and the Metaphysics of Modern Politics," Review of Politics. 48.1 (1986): 92-115.

Lerner, Ralph. "Commerce and Character: The Anglo-American as New Model Man," William and Mary Quarterly. 36.1 (January 1979): $3-26$.

Mason, Alpheus T. "The Federalist-A Split Personality," American Historical Review. 57.3 (April 1952): 625-643.

Mason, Cathy and Peter Onuf. "Toward a Republican Empire: Interest and Ideology in Revolutionary America," American Quarterly. 37.4 (Fall 1985): 496-531.

McCoy, Drew. "Madison's America, Polity, Economy and Society," The Quarterly Journal of the Library of Congress. $37.2(1980): 162-175$. 
. "Jefferson, Madison and Malthus: Population Growth in Jeffersonian Political Economy," Virqinia Magazine of History and Biography. 88.3 (1980): 259-276.

- "Republicanism and American Foreign Policy: James Madison and the Political Economy of Commercial Discrimination," William and Mary Quarterly. 31.4 (1974): 633-46.

Meyers, Marvin. "Revolution and the Founding: On PubliusMadison and the American Genesis," The Quarterly Journal of the Library of Congress. 37.2 (Spring 1980): 192-200.

Morgan, Robert J. "Madison's Theory of Representation in the Tenth Federalist," Journal of Politics. 36.4 (1974): $852-885$.

- "Madison's Analysis of the Sources of Political Authority," American Political Science Review. 75.3 (Sept. 1981): 613-25.

Onuf, Peter S. "Reflections on the Founding: Constitutional Historiography in Bicentennial Perspective," William and Mary Quarterly. (April 1989): 341-375.

Ostrom, Vincent. "The Meaning of Federalism in The Federalist Papers: A Critical Examination of the Diamond Thesis." Publius. 15.1 (1986): 1-21.

Peterson, Paul. "Federalism at the American Founding: In Defense of the Diamond Thesis," Publius. 15.1 (1986): 23-30.

Pocock, J.G.A. "Civic Humanism and Its Role in AngloAmerican Thought," Politics, Lanquage, and Time: Essays on Political Thought and History. (New York: Atheneum, 1973): 80-103.

- "The Machiavellian Moment Revisited: A Study in History and Ideology," Journal of World History. 53 (1981): 49-72.

Rakove, Jack N. "James Madison and the Extended Republic: Theory and Practice in American Politics," This Constitution. 3 (1984): 16-22.

- "The Madisonian Moment," University of Chicago Law Review. 55.2 (Spring 1988): 473-505.

Riemer, Neal. "The Republicanism of James Madison," Political Science Quarterly. 69 (March 1954): 45-64. 
Rutland, Robert. "Madison's Bookish Habits," Quarterly Journal of the Library of Congress. 37.2 (1980): 176191.

Shalhope, Robert E. "Toward a Republican Synthesis: The Emergence of an Understanding of Republicanism in American Historiography," William and Mary Quarterly. 29 (January 1972): 49-80.

- "Republicanism and Early American Historiography," William and Mary Quarterly. (April, 1982): 334-356.

Sheehan, Colleen Ann. "Cementing the Union: A Dialogue Concerning the True Principles of Republican

Government." Dissertation Abstracts International. 47.2 (1986): 648-A, DA8608766.

Thompson, D.F. "Education of a Founding Father: The Reading List for Witherspoon's Political Theory Course as Taken by James Madison," Political Theory. 4.4 (1976) : 52329.

Weber, Paul J. "James Madison \& Religious Equality: The Perfect Separation," Review of Politics. 44.2 (1982): $163-186$.

Wren, Thomas J. " The Ideology of Court and Country in the Virginia Ratifying Convention of 1788," Virginia Magazine of History and Biography. 93.4 (1985): 389407 .

Wright, Esmond. "The Political Education of James Madison," History Today. 31 (Dec. 1981) : 17-23.

Yarbrough, Jean. "Thoughts on the Federalist's View of Representation," Polity. 12.1 (1979): 65-82.

Zvesper, John. "The Madison Systems," Western Political Quarterly. 37.2 (1984): 236-56. 